\title{
Specific expression patterns and cell distribution of ancient and modern PAG in bovine placenta during pregnancy
}

\author{
Eve Touzard ${ }^{1,2}$, Pierrette Reinaud ${ }^{1}$, Olivier Dubois ${ }^{1}$, Catherine Guyader-Joly ${ }^{2}$, Patrice Humblot ${ }^{3}$, \\ Claire Ponsart ${ }^{2}$ and Gilles Charpigny ${ }^{1}$ \\ ${ }^{1}$ INRA, UMR1198, Biologie du Développement et Reproduction, F-78352 Jouy-en-Josas, France, ${ }^{2}$ UNCEIA, Union \\ Nationale des Coopératives d'Elevage et d'Insémination Animale, Recherche et Développement, F-94704 \\ Maisons-Alfort, France and ${ }^{3} S L U$, Department of Clinical Sciences, Faculty of Veterinary Medicine and Animal \\ Science, Swedish University of Agricultural Sciences, SE 75007 Uppsala, Sweden
}

Correspondence should be addressed to G Charpigny who is now at INRA, Domaine de Vilvert, UMR1198, Biologie du Développement et Reproduction, 78350 Jouy-En-Josas, France; Email: gilles.charpigny@jouy.inra.fr

\begin{abstract}
Pregnancy-associated glycoproteins (PAGs) constitute a multigenic family of aspartic proteinases expressed in the trophoblast of the ruminant placenta. In Bos taurus, this family comprises 21 members segregated into ancient and modern phylogenetic groups. Ancient PAGs have been reported to be synthesized throughout the trophoblastic cell layer whereas modern PAGs are produced by binucleate cells of cotyledons. The aim of this study was to investigate modern and ancient PAGs during gestation in cotyledonary and intercotyledonary tissues. To obtain convincing and innovative results despite the high sequence identity shared between PAGs, we designed specific tools such as amplification primers and antibodies. Using real-time RT-PCR, we described the transcript expression of 16 bovine PAGs. Overall, PAGs are characterized by an increase in their expression during gestation. However, we demonstrated a segregation of modern PAGs in cotyledons and of ancient PAGs in the intercotyledonary chorion, except for the ancient PAG2 expressed in cotyledons. By raising specific antibodies against the modern PAG1 and ancient PAG11 and PAG2, we established the expression kinetics of the proteins using western blotting. Immunohistochemistry showed that PAGs were produced by specific cellular populations: PAG1 by binucleate cells in the whole trophoblastic layer, PAG11 was localized in binucleate cells of the intercotyledonary trophoblast and the chorionic plate of the cotyledon, while PAG2 was produced in mononucleate cells of the internal villi of the cotyledon. These results revealed a highly specific regulation of PAG expression and cell localization as a function of their phylogenetic status, suggesting distinct biological functions within placental tissues.

Reproduction (2013) 146 347-362
\end{abstract}

\section{Introduction}

The ruminant placenta is characterized by specific structural and functional features: the placentomes. These structures are discrete areas of massive interdigitations between the maternal endometrium and the foetal chorioallantois, which facilitate communication and exchanges between the foetal and maternal compartments. The placentome combines embryonic and maternal villi called cotyledon and caruncle respectively. The external surface of the placenta is a single-cell layer, the trophoblast, which covers the cotyledonary and intercotyledonary areas. The trophoblast is made up of two different cell types: mononucleate cells that account for $80 \%$ of the total trophoblastic population and binucleate cells (Wooding \& Wathes 1980, Wooding 1983). Mononucleate cells play a fundamental role in the maternal recognition of pregnancy via the secretion of interferon- $\tau$ and in foetal nutrition via the absorption of uterine histotroph. Binucleate cells have been suspected as being involved in conceptus implantation and are essential to the maintenance of pregnancy via their endocrine function (Igwebuike 2006). Among the molecules produced by trophoblastic cells, the pregnancy-associated glycoprotein (PAG) multigenic family represents a set of proteins that is synthesized in the whole cellular layer (Zoli et al. 1992, Xie et al. 1994, Green et al. 2000). In Bos taurus, 21 PAG genes and 20 PAG-like genes have been identified in GENBANK (http://www.ncbi.nlm.nih.gov/nuccore/). PAGs are proteins whose molecular weights range from 37 to 90 kDa (Butler et al. 1982, Xie et al. 1991, 1994, Zoli et al. 1991, Szafranska et al. 2006). They belong to the large family of aspartic proteinases. However, the function of PAG remains unknown. Hypotheses concerning the modulation of immune activity (Dosogne et al. 1999, 2000) and the maintenance of 
pregnancy (Weems et al. 1998, 1999, 2001, Bridges et al. 1999, Thompson et al. 2012) have been investigated to date.

Phylogenetic studies have shown that PAGs segregate into one ancient group and a more recent group (Green et al. 2000, Hughes et al. 2000). The latter refers to modern molecules that appeared about 52 millions years ago, whereas the ancient group includes members that have probably existed for about 87 millions years. Modern PAGs, typified by PAG1, have been extensively characterized and are known to be synthesized in binucleate cells of the cotyledon (Xie et al. 1991, Zoli et al. 1992, Green et al. 1998, Wooding et al. 2005). In contrast, ancient PAGs (PAG2, PAG8, PAG10, PAG11, PAG12 and PAG13) have been poorly described. According to earlier studies, ancient PAGs were reported to be expressed throughout the trophoblastic cell layer (Xie et al. 1994, Green et al. 2000) or at the junction between the cotyledonary trophoblast and caruncular endometrium (Wooding et al. 2005). Doubt remains regarding the reliability and accuracy of the data available on the location and expression of PAGs in the ancient group. Because modern PAGs have been widely used as pregnancy markers to detect gravid cows, considerable attention has been paid to describing PAGs in the maternal circulation (Sasser et al. 1986, Mialon et al. 1993). Many other studies have focused on the characterization of PAGs in the cotyledon (Xie et al. 1991, Klisch \& Leiser 2003, Wooding et al. 2005, Telugu et al. 2009) as the principal placental region that produces modern PAGs for delivery into the maternal blood flow. There is relevant evidence in favour of PAG expression in the intercotyledonary chorion (Patel et al. 2004b, Wooding et al. 2005). However, no exhaustive analysis has been made of most PAGs in the two phylogenetic groups and taking account the two regions of the placenta. Moreover, the focus of most studies has been at the mRNA level. With the exception of PAG1, the problems encountered in trying to purify the different PAGs from placental extracts without cross-contamination have not enabled the generation of strictly specific antibodies (Butler et al. 1982, Xie et al. 1991, Wooding et al. 2005).

The aim of this study was therefore to exhaustively characterize bovine PAG expression in both the villous areas of cotyledons and the intercotyledonary chorion, at both the mRNA and protein levels. In an attempt to produce convincing and reliable results, we developed specific tools such as RT-PCR primers and antibodies. Immunohistochemistry analyses were also performed in order to determine the regional and cellular expression of PAG proteins. We investigated the expression and localization patterns of PAG in placental tissues from day 60 of gestation (when secondary and tertiary villi are established) resulting in a differentiated and visible cotyledon.

\section{Materials and methods}

\section{Animals and sample collection}

All procedures relating to the care and use of animals were carried out in accordance with the International Guiding Principles for Biomedical Research Involving Animals, as promulgated by the Society for the Study of Reproduction, and with the European Convention on Animals approved by the French Ministry of Agriculture under French regulations (86/609/EEC, updated on 04/19/1988). The experiments were approved by the local ethics committee (Comethea registration numbers: 12/082 for cows and 12/061 for rabbits). The cows were housed at the Union Nationale des Coopératives d'Elevage et d'Insémination Animale (UNCEIA) experimental facilities (Chateauvilain, France). Oestrus cycles were synchronized using the Crestar method on Holstein breed cows, and artificial insemination was performed as described previously (Constant et al. 2011). Six to eight cows per stage of gestation were killed at a local slaughterhouse. The cotyledons and intercotyledonary chorion were collected at $60,80,100$ or 220 days post insemination (dpi). One half of the tissue was snap frozen in liquid nitrogen and stored at $-80^{\circ} \mathrm{C}$ until analysis and the other half was fixed for immunochemistry analyses.

\section{Design and validation of gene-specific PCR primers}

Transcript sequences for bovine PAG were retrieved with the ENTREZ Nucleotide using the Reference Sequence database from GENBANK (http://www.ncbi.nlm.nih.gov/nuccore/). When RefSeq data were not available (PAG3, PAG13 and PAG14), we used predicted mRNA sequences. Pseudogenes were excluded from this study. As previously shown (Telugu et al. 2009), we determined that PAG22 (AY911498) was PAG2 (NM_176614). Transcript-specific PCR primer couples were designed using the eprimer3 program of EMBOSS 6.3.1 software using the 'Primer3 mispriming library' section (Rice et al. 2000). We included in this library all PAG nucleotide sequences for which we wanted to exclude the non-specific crossing of primers. Primer specificity was verified by sequencing the amplicon produced after the amplification of cDNA from extra-embryonic tissues collected at 60 and $100 \mathrm{dpi}$. The PCR cycling conditions were as follows: single denaturation step at $94{ }^{\circ} \mathrm{C}$ for $60 \mathrm{~s}$, then DNA denaturation step at $94{ }^{\circ} \mathrm{C}$ for $30 \mathrm{~s}$, primer annealing step at $60^{\circ} \mathrm{C}$ for $30 \mathrm{~s}$ and a polymerase extension step at $72{ }^{\circ} \mathrm{C}$ for $30 \mathrm{~s}$. PCR was performed on a BIOMETRA apparatus for 35 cycles. A final elongation step was performed at $72{ }^{\circ} \mathrm{C}$ for $15 \mathrm{~min}$. Amplicons were purified and cloned into pGEM-T Easy vector (Promega) in subcloning $\mathrm{DH} 5 \alpha$ competent cells (Invitrogen). Purified PCR fragments were sequenced by Beckman Coulter Genomics (Takeley, Essex, UK) and their identity was investigated in GENBANK using the NCBI Basic Local Alignment Search Tool (http://blast.ncbi.nlm.nih.gov/) for nucleic acid sequences. PCR primer couples corresponding with authenticated fragments were validated and used for the amplification experiments (see Table 1).

\section{Evaluation of PAG gene expression between 60 and 220 dpi}

Total RNA was extracted from tissues using the phenolbased method described by Chomczynski \& Sacchi (1987). The 
Table 1 Sequence of primers for real-time quantitative PCR.

\begin{tabular}{|c|c|c|c|c|}
\hline \multirow[b]{2}{*}{ Gene name } & \multirow[b]{2}{*}{ Accession number } & \multicolumn{2}{|c|}{ Oligonucleotide primer sequence $5^{\prime}-3^{\prime}$} & \multirow{2}{*}{$\begin{array}{c}\text { Product size } \\
\text { (bp) }\end{array}$} \\
\hline & & Forward & Reverse & \\
\hline PAG1 & M73962 & GGTACСССТGATCCAAGC & TATGGCACCGATGAGCCTAT & 172 \\
\hline PAG2 & L06151 & GTATCCTGGGCTTGGCTTTT & СССТCTGGCTTGTTTGTGTT & 183 \\
\hline PAG3 variant 1 & XM_002699276 & GGGCAGAGCTTATTATGATGG & TCTTGGGCCTTCTATTGCTG & 340 \\
\hline PAG4 & AF020506 & CСACCAAGGTGTGAATGCTT & CAGGCTTCTGTCCATGTGATT & 202 \\
\hline PAG5 & AF020507 & CAGGCAGGTGAGTGGAGTCT & GGCAGGGATATGACAGCAAA & 209 \\
\hline PAG6 & AF020508 & TGGGTCCTCAGTACTTCGTTT & TCAGCACCCGTTAAGTGAAA & 412 \\
\hline PAG7 variant 2 & AF020509 & TCGATCGATTGCAACAGTACA & TTGTGCGCAAACCCATATT & 215 \\
\hline PAG8 & BC133476 & ССТGTGCССССТGACTACTA & GTAGCAGCCCGAATTTATGC & 206 \\
\hline PAG10 & AF020512 & GCCСAAGCTTACATCCAAAG & АTTCCTGAAGTAGCCCAGCA & 192 \\
\hline PAG11 & AF020513 & AGTGATTGGCTGTGAACACG & CACGAGGCACTGAGTAATCG & 206 \\
\hline PAG12 & AF020514 & CACCAGGGTTCGGAGTATGT & GGCAGAAGTTTTGAGCCTTG & 130 \\
\hline PAG15 & AF192332 & ACGGATCTGGGACAATGG & ATACCCCGGTGTCAACAA & 426 \\
\hline PAG16 & AF192333 & ATTCGAGCAGGTGACTG & TGTAGATCTCСТСАСТСТTTGСТС & 333 \\
\hline PAG17 & AF192334 & CGGCATACCCAAAAGGTCT & ACCGTCAAACCCAАCTTCTG & 144 \\
\hline PAG19 & AF192336 & AGAATACGGGCTTGAGCATA & TTTССССТGTAATAGCGATG & 210 \\
\hline PAG20 & AF192337 & CCGGGTCATCAAATATCCAA & GACAACAGAGGGCAGAGCAC & 128 \\
\hline PAG21 & AF192338 & TCGAGGATTTGATGTACGTG & TGCCATCATAAGCTCTGTCC & 327 \\
\hline ACTB & BC102948 & GACTACСТСАТGAАGАТССТС & CGGATGTCCACGTCACACTTC & 320 \\
\hline RPL19 & BC102223 & ССССААТGАGАССААТGАААТС & CAGCССАТСТTTGATCAGСТT & 73 \\
\hline GAPDH & BC102589 & GCTGACGCTCCCATGTTTGT & TCATAAGTCССТССАСGATGC & 151 \\
\hline
\end{tabular}

concentration and purity of RNA samples were determined by spectrophotometry at 260 and $280 \mathrm{~nm}$. To estimate RNA integrity, $2 \mu \mathrm{g}$ of the extract were separated by $0.8 \%$ agarose gel electrophoresis under neutral conditions and stained with ethidium bromide. One microgram of total RNA was reverse transcribed into cDNA using $100 \mathrm{IU}$ of Moloney murine leukaemia virus enzyme and $0.5 \mu \mathrm{g} / \mu$ l oligo-dT $12-18$ primers (Invitrogen), in a total volume of $20 \mu \mathrm{l}$ at $37^{\circ} \mathrm{C}$ for $1 \mathrm{~h}$. Gene expression analysis was performed using real-time quantitative PCR with the SYBRGreen detection assay. The primer pairs are listed in Table 1. The expression of PAG genes was analysed using previously designed primers. $\beta$-Actin $(A C T B)$, glyceraldehyde 3-phosphate dehydrogenase $(G A P D H)$ and ribosomal protein L19 (RPL19) were selected as the bovine reference genes for normalization (Table 1). Each amplified PCR fragment was sequenced to assess the amplification of the correct gene. The calculation of amplification efficiency was based on the generation of standard curves using serial dilutions of known concentrations of cloned target amplicons, thus enabling the determination of copy numbers. Two measurements of each sample were performed as technical replicates. Briefly, 5\% of the cDNA was added as the PCR template to $12.5 \mu \mathrm{l} 2 \times$ SYBRGreen PCR Master Mix (Applied Biosystems), with $300 \mathrm{nM}$ of each forward and reverse primer in a final volume of $25 \mu$ l. PCR was performed on the StepOnePlus Real-Time PCR apparatus (Applied Biosystems) using universal cycling conditions: $95^{\circ} \mathrm{C}$ for $10 \mathrm{~min}$, then 40 cycles at $95^{\circ} \mathrm{C}$ for $15 \mathrm{~s}$ and $60^{\circ} \mathrm{C}$ for $1 \mathrm{~min}$, followed by a melting curve verification step. The data were analysed using StepOne Software v2.2.2 (Applied Biosystems).

\section{Peptide design for protein-specific polyclonal antibodies and immunoglobulin purification}

The 'Antigenic' program of the EMBOSS 6.3.1 software (Kolaskar \& Tongaonkar 1990) was used to identify antigenic determinants (epitopes) from the amino acid sequences of PAG2 (NP_788787) and PAG11 (NP_788796). Epitopes were selected according to their capacity to generate antibodies. This capacity was calculated in relation to the physicochemical properties of the amino acid residues and their frequencies of occurrence. Identified sequences were compared with the complete peptidic sequences of all other PAGs using the NCBI Basic Local Alignment Search Tool and the EBI ClustalW2 multiple sequence alignment tool (http://www.ebi.ac.uk/Tools/ msa/clustalw2/) to preserve only specific sequences and prevent any inconvenient crossovers. Epitope sequences were used as templates by Proteogenix (Schiltigheim, France) to synthesized corresponding peptide and keyhole limpet hemocyanin (KLH)-conjugated peptides. The PAG1 protein was purified as previously described (INRA patent n ${ }^{\circ}$ FR-88 03590 and Camous et al. (1988)) with minor modifications. The monitoring of PAG in all steps of the purification process was performed using a RIA previously developed (Mialon et al. 1993). Briefly, day 150-200 bovine placental cotyledons were homogenized in $0.05 \mathrm{M}$ phosphate buffer at $\mathrm{pH} 8.6$ containing $0.1 \mathrm{M} \mathrm{KCl}$ and $20 \mu \mathrm{M}$ phenylmethanesulfonyl fluoride at $4{ }^{\circ} \mathrm{C}$, using an Ultra-Turrax homogenizer. The total protein extract was acid precipitated at $\mathrm{pH}$ 4.3. After centrifugation, the supernatant was fractionated by precipitation with ammonium sulphate at $\mathrm{pH}$ 5.2. The 40-65\% saturated ammonium sulphate fraction was extensively dialysed against $0.05 \mathrm{M}$ Tris/HCl buffer at $\mathrm{pH}$ 8.6. The protein preparation was chromatographed onto a DEAE Sephadex A50 (GE Healthcare Life Sciences, VelizyVillacoublay, France) column and the protein fractions were eluted by increasing ionic strength using a stepwise gradient of $\mathrm{KCl}$ in $0.05 \mathrm{M}$ Tris/ $\mathrm{HCl}$ buffer at $\mathrm{pH}$ 8.6. The $0.3 \mathrm{M} \mathrm{KCl}$ fraction was dialysed and concentrated by ultrafiltration and then submitted to cation exchange HPLC chromatography using a TSK-SP 5PW column $(21.5 \times 150 \mathrm{~mm}$; Tosoh Bioscience $\mathrm{GmbH}$, Stuttgart, Germany). Proteins were eluted at a flow rate of $4 \mathrm{ml} / \mathrm{min}$ by a linear gradient of $\mathrm{KCl}$ in the Tris buffer and the protein elution was monitored by u.v. at $280 \mathrm{~nm}$. Finally, the PAG1/PSP60-positive fractions were collected and concentrated by ultrafiltration and next chromatographed onto 
a size exclusion TSK-G3000 PW column $(7.8 \times 600$ mm; Tosoh Bioscience $\mathrm{GmbH}$ ). These chromatographic processes enabled the purification of a single PAG1/PSP60 protein eluting as a discrete peak. The protein appeared at a unique band around $65 \mathrm{kDa}$ in SDS-PAGE. The N-terminal protein sequence of the first 40 residues (NGSNLTTHPLRNIKDLVYMGNITIGTPPQEFQVVFDTASS-) identified this protein originally called PSP-60 in our laboratory (Camous et al. 1988, Mialon et al. 1993) at the referred polypeptide chain of bovine PAG1 (UniProtKB accession number: Q29432; Genbank accession number: AAB35845). PAG2 peptides, PAG11 peptides and native PAG1 protein were used to raise anti-PAG2, anti-PAG11 and anti-PAG1 polyclonal antibodies. Antibodies were generated using two New Zealand White rabbits per antigen. The rabbits were primed with an intradermal injection of $80 \mu \mathrm{g}$ PAG1 or $80 \mu \mathrm{g}$ KLH-conjugated peptide emulsified in complete Freund's adjuvant (Sigma-Aldrich), followed by several booster immunizations at 3-week intervals with $40 \mu \mathrm{g}$ protein or KLH-conjugated peptides in incomplete Freund's adjuvant (Sigma-Aldrich). Blood samples were collected 10 days after each injection, starting from the second month after the first antigen injection. Immune sera were separated from whole blood samples after centrifugation for $30 \mathrm{~min}$ at $3500 \mathrm{~g}$ and at $4{ }^{\circ} \mathrm{C}$ and then stored at $-20{ }^{\circ} \mathrm{C}$. Immunoglobulins were purified from anti-PAG1 (L520), anti-PAG2 (L390) and antiPAG11 (L349) immune sera by affinity chromatography onto an Hitrap NHS-activated HP pre-packed column (GE Healthcare). The protein or peptides were first immobilized on the column according the manufacturer's instructions. The columns were equilibrated with $20 \mathrm{mM}$ phosphate buffer at $\mathrm{pH} 7.1$. Immunoglobulins were eluted with $0.2 \mathrm{M}$ glycine $/ \mathrm{HCl}$ at $\mathrm{pH}$ 2.8 and then dialysed and concentrated against a neutral phosphate buffer using an Amicon ultrafiltration unit with a YM10 membrane (Millipore, Guyancourt, France).

\section{Western blot analysis}

Placental proteins were extracted from small pieces of tissue by sonication in a cold lysis buffer at $\mathrm{pH} 7.4$ containing $50 \mathrm{mM}$ HEPES, $150 \mathrm{mM} \mathrm{NaCl}, 5 \mathrm{mM}$ EDTA, 16 mM 3-[(3-cholamidopropyl) dimethylammonio]-2-hydroxy1-propanesulfonate, $1 \mathrm{mM}$ benzamidine $\mathrm{HCl}, 1 \mathrm{mM}$ phenylmethylsulfonyl fluoride, $10 \mu \mathrm{g} / \mathrm{ml}$ soybean trypsin inhibitor, $10 \mu \mathrm{g} / \mathrm{ml}$ leupeptin and $10 \mu \mathrm{g} / \mathrm{ml}$ aprotinin. Protein quantification was performed with the Bio-Rad protein assay (Bio-Rad) using BSA as the standard (Sigma-Aldrich). Twenty micrograms of each sample were separated by 10\% SDS-PAGE and electro-transferred onto a Hybond-P PVDF membrane (GE Healthcare). Protein molecular weight markers (ProSieve Color Protein Markers, Lonza, Levallois-Perret, France) and samples were run simultaneously. After washing in Tris-buffered saline containing Tween 20 (TBST) (50 mM Tris at pH 7.5, $137 \mathrm{mM}$ $\mathrm{NaCl}$ and $0.1 \%$ Tween 20), the membranes were blocked in $2 \%$ TBST BSA and $0.2 \%$ Tween 20 overnight at $4{ }^{\circ} \mathrm{C}$. Dedicated blots were probed for $2 \mathrm{~h}$ at room temperature with immunoglobulin anti-PAG1, anti-PAG11 and anti-PAG2 diluted in $2 \%$ TBST BSA $0.2 \%$ Tween 20 used at a final concentration of $0.5,0.4$ and $1.7 \mu \mathrm{g} / \mathrm{ml}$ respectively. Peroxidase-conjugated donkey anti-rabbit IgG (Jackson ImmunoResearch, Interchim,
Montluçon, France) was used as the secondary antibody, diluted to $1: 20000(\mathrm{vol} / \mathrm{vol})$ and incubated for $1 \mathrm{~h} 30 \mathrm{~min}$ at room temperature. Two negative control experiments were also performed: in the first case the primary antibodies were omitted and in the second the primary antibody was neutralized with the peptide or protein used as the immunogen. Antibodies were pre-incubated for $30 \mathrm{~min}$ at $38^{\circ} \mathrm{C}$ with $10 \mu \mathrm{g}$ of the respective protein or peptide per microgram of immunoglobulin. To control for variations in extraction and loading, each blot was probed with rabbit polyclonal anti-GAPDH (diluted 1:1000; Santa Cruz) after stripping the membranes for $30 \mathrm{~min}$ at $56{ }^{\circ} \mathrm{C}$ in $50 \mathrm{mM}$ Tris/ $\mathrm{HCl}, 2 \% \mathrm{SDS}$ and $100 \mathrm{mM} \beta$-mercaptoethanol. The antibodies were examined for cross-reactions in slot blot assays. Proteins and peptides were diluted in $50 \mathrm{mM}$ Tris/ $\mathrm{HCl}$ at $\mathrm{pH} 7.5$ containing $0.005 \%$ bromophenol blue. Different loading volumes were used to increase the quantity range of the peptides and protein. Samples were blotted onto a PDVF membrane using a Manifold II SRC 072/00 blotter (Schleicher \& Schuell, Dassel, Germany). The membranes were probed as for western blot. Immunoreactive signals were revealed with the Pierce western blot signal enhancer reagent system (Thermofisher, Illkirch, France) and chemiluminescence was visualized using a CCD camera (LAS1000, Fujifilm, Düsseldorf, Germany). The data were analysed with Advanced Image Data Analyser Software (Raytest, La Defense, France).

\section{Enzymatic N-deglycosylation}

Protein extracts from the cotyledon and intercotyledonary chorion harvested at $220 \mathrm{dpi}$ were subjected to enzymatic digestion to remove oligosaccharides using peptide $\mathrm{N}$-glycosidase $\mathrm{F}$ (New England Biolabs, Evry, France) according to the supplier's instructions. Briefly, $20 \mu \mathrm{g}$ of the total protein extract were denatured for $10 \mathrm{~min}$ at $100{ }^{\circ} \mathrm{C}$ in glycoproteindenaturing buffer at a final volume of $10 \mu \mathrm{l}$. After cooling, the samples were treated with 100 IU PNGase-F for 2, 5, 15, 30, 90 and $360 \mathrm{~min}$ at $37^{\circ} \mathrm{C}$. Mock-treated protein extracts were incubated without the enzyme as controls. The reaction was terminated by PNGase-F inactivation under incubation at $75^{\circ} \mathrm{C}$ for $10 \mathrm{~min}$. The samples were then frozen in liquid nitrogen until western blot analysis as described earlier.

\section{Immunohistochemical investigations}

After 4 -h fixation in $4 \%$ paraformaldehyde in $0.1 \mathrm{M}$ phosphate buffer, $\mathrm{pH} 7.5$, at $4{ }^{\circ} \mathrm{C}$ and a wash in the same buffer, all samples were embedded in paraffin (Paraplast plus, Sigma-Aldrich) in an automated system (Shandon Citadel Tissue Processor; Thermofisher) and stored at $4{ }^{\circ} \mathrm{C}$. Sections of tissue were cut at microtome settings of 5 or $8 \mu \mathrm{m}$ with an RM2245 apparatus (Leica Microsystems SAS) and recovered on Super Frost Plus slides (Thermofisher). The tissue sections were deparaffinized in xylene and rehydrated stepwise in ethanol (100, 95, 70 and $30 \%$ ) followed by a final rehydration in $0.1 \mathrm{M}$ phosphate buffer at $\mathrm{pH}$ 7.5. Individual sections were enclosed in a hydrophobic barrier using an ImmEdge pen (Vector Laboratories, Clinisciences, Nanterre, France) and treated successively for antigen unmasking in $0.01 \mathrm{M}$ trisodium citrate at $\mathrm{pH} 6.0$ for $5 \mathrm{~min}$ at room temperature and then $10 \mathrm{~min}$ at $80^{\circ} \mathrm{C}$. To quench 
endogenous peroxidase activity, the slides were treated for $30 \mathrm{~min}$ with $0.1 \%$ hydrogen peroxide (by volume). The primary antibody was used as a purified immunoglobulin at 0.05, 0.4 and $1.7 \mu \mathrm{g} / \mathrm{ml}$ for PAG1, PAG11 and PAG2 respectively. Antibodies were diluted in $0.1 \mathrm{M}$ phosphate buffer at $\mathrm{pH} 7.5$ containing 2\% BSA (wt/vol) and donkey serum diluted 1:100 (vol/vol). The slides were incubated overnight at $4{ }^{\circ} \mathrm{C}$ with the primary antibody. After two washes in $0.1 \mathrm{M}$ phosphate buffer at $\mathrm{pH} 7.5$ containing $0.2 \% \mathrm{BSA}$, the slides were incubated for $1 \mathrm{~h}$ at room temperature with the secondary biotinylated donkey anti-rabbit antibody (Jackson ImmunoResearch) diluted 1:1000 ( $\mathrm{vol} / \mathrm{vol})$ in $0.1 \mathrm{M}$ phosphate buffer at $\mathrm{pH} 7.5$ with $2 \%$ BSA. As for western blotting, two negative control experiments were carried out. The primary antibody was either omitted or immunoneutralized by an excess of the protein or peptide. The slides were then incubated for $1 \mathrm{~h}$ with Vectastain Elite ABC-HRP reagent (Vector Laboratories) in $50 \mathrm{mM}$ Tris/ $\mathrm{HCl}$ buffer at $\mathrm{pH} 7.6$ to activate the avidin-biotin peroxidase complex. After washing in the same buffer, the peroxidase was visualized with nickel-enhanced diaminobenzidine tetrahydrochloride chromogen $(5 \mathrm{mg} / \mathrm{ml}$ ammonium nickel (II) sulphate; $0.5 \mathrm{mg} / \mathrm{ml}$ diaminobenzidine tetrahydrochloride). Incubation was performed at $25{ }^{\circ} \mathrm{C}$ for 5 min to achieve purple staining. Finally, the sections were fixed in $2 \%$ paraformaldehyde for $5 \mathrm{~min}$ and gradually dehydrated in successive baths of $90 \%$ ethanol, $100 \%$ ethanol, $50 \%$ ethanol-50\% Neo-Clear (vol/vol) (Merck) and 100\% Neo-Clear. The tissue sections were mounted using permanent Neo-Mount medium (Merck).

The simultaneous immunodetection of PAG1 and PAG11 on the one hand and of PAG1 and PAG2 on the other hand was performed using double immunoenzymatic labelling. PAG2 and PAG11 were first located according to the protocol described earlier. However, to enable compatibility between the chromogens, the bound antibodies were visualized using ImmPACt Novared peroxidase substrate (Vector Laboratories) according to the supplier's instructions. After peroxidase detection, the tissue sections were washed twice for $5 \mathrm{~min}$ in $0.1 \mathrm{M}$ phosphate buffer at $\mathrm{pH} 7.5$ containing $0.2 \% \mathrm{BSA}$ and incubated for $30 \mathrm{~min}$ at $38^{\circ} \mathrm{C}$ in $0.2 \mu \mathrm{g} / \mathrm{ml}$ alkaline phosphatase-conjugated anti-PAG1 immunoglobulin. The anti-PAG1 immunoglobulin had previously been covalently bonded to alkaline phosphatase using the lightning-link AP conjugation kit (Innova Biosciences, Interchim, Montluçon, France). After two washes in $0.1 \mathrm{M}$ phosphate buffer at $\mathrm{pH} 7.5$, the slides were incubated for $30 \mathrm{~min}$ with Vector Blue alkaline phosphatase substrate (Vector Laboratories) in $0.1 \mathrm{M}$ Tris/ $\mathrm{HCl}$ at pH 8.2 containing $0.1 \%$ Tween 20 according to the supplier's instructions. The slides were then rinsed, dehydrated and mounted as described earlier. Photomicroscopies were captured using the NanoZoomer Digital Pathology System and images were visualized with NDPview (NanoZoomer Digital Pathology Virtual Slide Viewer Software, Hamamatsu, Massy, France). The experiments were repeated on three different placental sections from two 220 dpi cows.

\section{Statistical analyses}

Quantitative results were analysed using SYSTAT software v11 (Systat Software, Inc., Erkrath, Germany). The data were subjected to two-way ANOVA with the day of gestation and the type of placental tissues (cotyledonary and intercotyledonary chorion) as the main categories and day-by-tissue interactions. If a day-by-tissue interaction was evidenced, one-way ANOVA was performed and followed by pairwise comparisons using the Bonferroni adjustment. Data are expressed as least squares means \pm S.E.M.

\section{Results \\ Design and validation of gene-specific PCR primers}

Specific amplification primers were successfully designed for 16 of the 21 PAGs. PCR was thus performed on extra-embryonic tissues at two stages of gestation (days 60 and 100) with amplification of a single fragment. A BLAST search indicated $100 \%$ identity of the generated amplicons with the targeted PAGs.

\section{Expression of PAG genes in the cotyledon and intercotyledonary chorion during gestation}

ANOVA indicated that PAG mRNAs could be assigned to three different sets as a function of their distribution between different placental zones (Figs 1, 2 and 3). The first set included PAG1, PAG2, PAG3, PAG15, PAG17 and $P A G 21$, which were twice to four times more expressed in the cotyledonary tissue than in the intercotyledonary chorion $(P<0.001)$ where they remained at low levels (Fig. 1). For all these genes, two-way ANOVA highlighted an interaction between tissue distribution and the day of gestation $(P<0.001)$. This illustrated a marked increase in gene expression in the cotyledon as a function of the day of gestation but few changes in the intercotyledonary chorion. One-way ANOVA indicated that PAG1 was increasingly expressed in the cotyledon $(P<0.001)$. Pairwise comparisons revealed that PAG1, which was at its lowest levels on day 60, increased significantly from days 60 to $80(P<0.001)$, remained at steady-state levels between days 80 and $100(P<0.01)$ and was expressed at its highest levels on day $220(P<0.001)$. In the intercotyledonary chorion, PAG1 slightly increased during gestation $(P<0.01)$ with the most significant difference between days 60 and $100(P<0.05)$. In the cotyledon, PAG2, which was at its lowest levels on day 60 , increased significantly from days 60 to $80(P<0.001)$, decreased by day $100(P<0.01)$ and became expressed at its highest levels by day $220 \quad(P<0.001)$. In the intercotyledonary chorion, the expression of PAG2 progressively decreased $(P<0.01)$ with the most significant difference between days 60 and $220(P<0.001)$. In the cotyledon, PAG3 exhibited a similar profile to PAG1, with the highest levels of expression on day 220 compared with day $60(P<0.001)$, day $80(P<0.001)$ and day $100(P<0.001)$. No difference was observed between days 80 and 100 of gestation. In the intercotyledonary chorion, PAG3 was expressed at low levels on day 80 compared with day $220(P<0.01)$. In the 


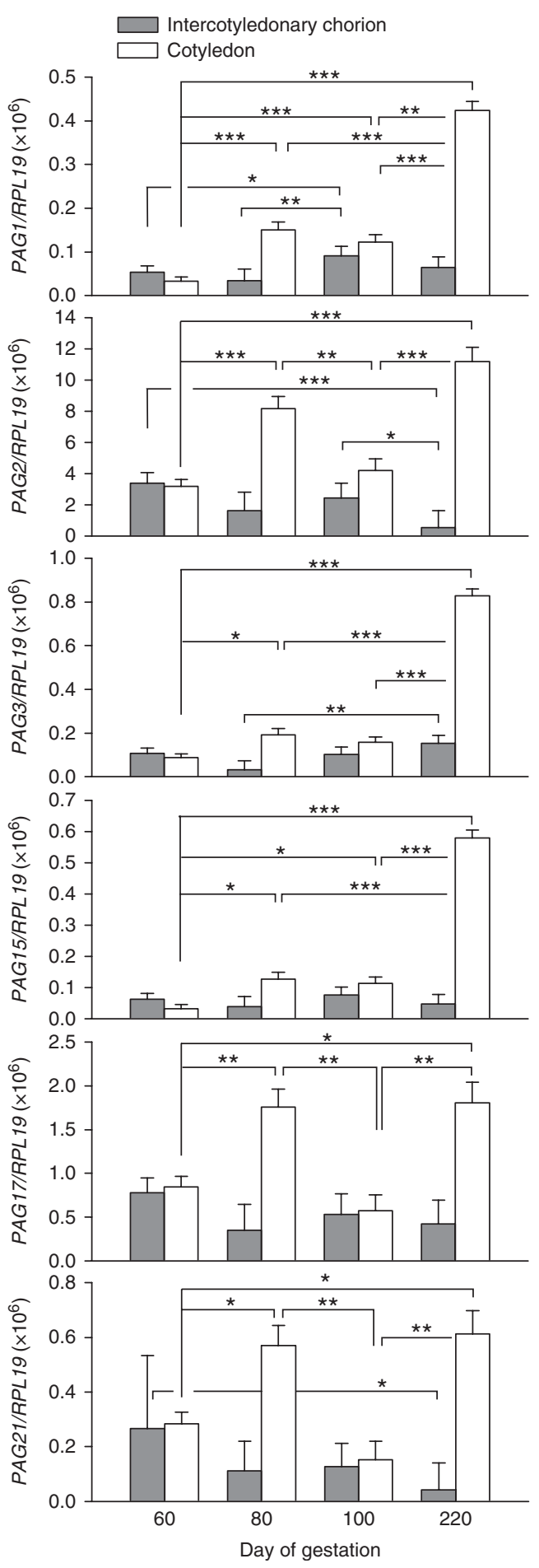

Figure 1 Expression of modern PAG1, PAG3, PAG15, PAG17 and PAG21 and ancient PAG2 in the placental chorion from 60 to $220 \mathrm{dpi}$. This group represents PAGs that are mainly expressed in the cotyledon $(P<0.001$ for PAG1, PAG2, PAG3, PAG15, PAG17 and PAG21). Intercotyledonary and cotyledonary chorion specimens were collected from pregnant cows at 60, 80, 100 and $220 \mathrm{dpi}$ (cows $=6-8$ per stage). PAG mRNAs were quantified by RT-qPCR and the results were normalized to RPL19. Data are presented as mean \pm s.E.M. Pairwise tests of mean differences were performed after significant one-way ANOVA: ${ }^{*} P<0.05 ;{ }^{* *} P<0.01 ;{ }^{* * *} P<0.001$. cotyledon, PAG15 displayed similar gene expression profile to PAG1 and PAG3. PAG15 was at its highest levels on day 220 compared with day $60(P<0.001)$, day $80(P<0.05)$ and day $100(P<0.05)$. The levels of expression were similar between days 80 and 100 $(P>0.05)$. No differences in PAG15 expression levels were observed in the intercotyledonary chorion. In the cotyledon, PAG17 and PAG21 showed similar patterns of expression to PAG2 with two maxima on days 80 and 220 and two minima on days 60 and 100. PAG17 and PAG21 were twofold more abundant on days 80 and 220 than on days 60 and $100(P<0.01)$. In the intercotyledonary chorion, no changes in PAG17 expression were observed throughout the gestation whereas PAG21 was expressed at lower levels on day 220 compared with day 60 $(P<0.05)$. The second set comprised PAG8, PAG10, PAG11 and PAG12 (Fig. 2). These PAGs were strongly expressed in the intercotyledonary chorion between days 60 and 220 of gestation whereas they only displayed weak expression in the cotyledon $(P<0.001)$. PAG8, PAG10, PAG11 and PAG12 were respectively 5-, 21-, 26and 4-fold, respectively, more strongly expressed in the intercotyledonary chorion than in the cotyledon. According to the mRNA copy numbers, PAG 8 was the most strongly expressed transcript in this second set. PAG8, PAG10 and PAG11 were significantly affected by a day-by-placental zone interaction $(P<0.001)$. In the intercotyledonary chorion, PAG8, PAG10 and PAG11 regularly increased during the gestation $(P<0.001)$ (Fig. 2). However, the increase in gene expression was more significantly pronounced in late gestation than in early and middle gestation (day 220 vs day 60: PAG8 $(P<0.001)$, PAG10 $(P<0.001)$ and PAG11 $(P<0.001))$. $P A G 8$ remained nearly unchanged until day 220. PAG10 was significantly augmented on day 100 (day 60 vs day 100: $P<0.05)$ and reached maximum levels on day 220 (day 60 vs day 220: $P<0.001$ ). The level of $P A G 11$ increased gradually from days 60 to 100 and was intensively up-regulated on day 220 (day 60/day 80/day 100 vs day 220: $P<0.001)$. PAG12 was expressed at constant levels in the two placental zones whatever the day of gestation. In the cotyledon, PAG8 and PAG11 were expressed at constant and low levels while PAG10 exhibited a small increase on day 220 compared with the other periods of gestation $(P<0.001)$. The third set contained PAG7 and PAG16, which were not differentially expressed between the cotyledon and intercotyledonary chorion $(P>0.05)$ (Fig. 3). In the cotyledon, PAG7 was expressed at similar levels throughout the period of gestation studied. In the intercotyledonary chorion, PAG7 was at its lowest level on day 80 and this was significantly different to that on day $60(P<0.01)$. PAG16 was differentially expressed between days of gestation in both placental zones. In the cotyledon, PAG16 expression was higher on day 220 compared with day $100(P<0.05)$ and day $60(P<0.01)$. In the intercotyledonary chorion, PAG16 expression differed between days 80 and 100 

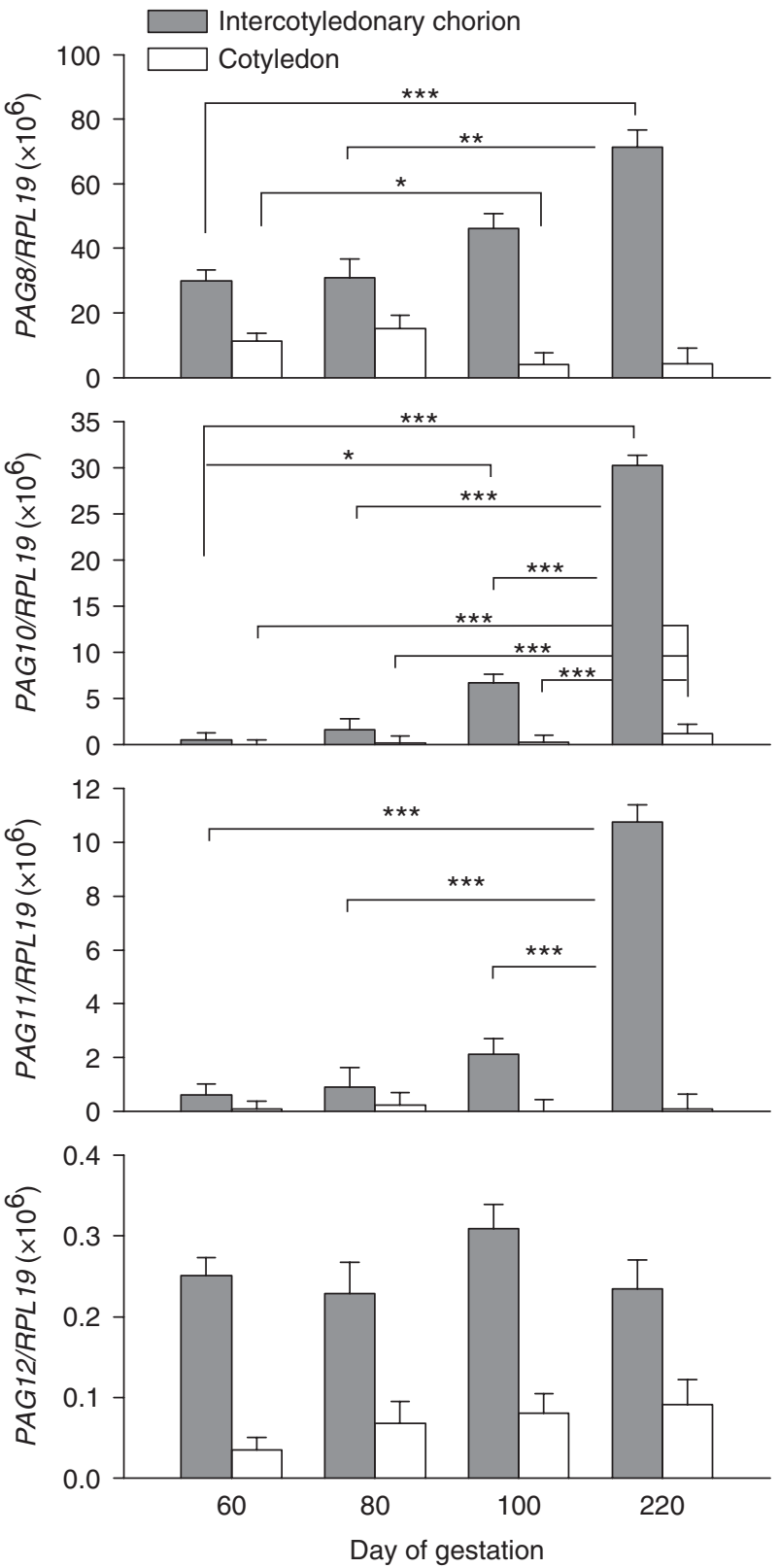

Figure 2 Expression of ancient PAG8, PAG10, PAG11 and PAG12 in the placental chorion from 60 to $220 \mathrm{dpi}$. This group represents PAGs that are mainly expressed in the intercotyledonary chorion $(P<0.001$ for PAG8, PAG10, PAG11 and PAG12). Intercotyledonary and cotyledonary chorion specimens were collected from pregnant cows at 60, 80, 100 and 220 dpi (cows $=6-8$ per stage). PAG mRNAs were quantified by RT-qPCR and the results were normalized to RPL19. Data are presented as mean \pm S.E.M. Pairwise tests of mean differences were performed after significant one-way ANOVA: ${ }^{*} P<0.05 ;{ }^{* *} P<0.01$; $* * * P<0.001$.

$(P<0.01)$. Finally, the levels of expression of four other PAG (PAG4, PAG5, PAG6 and PAG19) were determined. Because they were expressed at low levels close to the limit of detection of real-time PCR, and because they displayed no significant variations, the data on them are not shown. We observed that set-1 comprised modern
PAGs whereas set-2 (characterized by expression in the intercotyledonary chorion) contained exclusively ancient PAGs. However, PAG2, which was expressed in the cotyledon but not in the intercotyledonary chorion, belonged to the ancient group.

\section{PAG expression in the cotyledon and intercotyledonary chorion during gestation}

The partitioning of PAG between the cotyledon and intercotyledonary chorion as evidenced by the study of mRNA was also examined at the protein level. This investigation was performed on three PAGs, two of which were representative of the two main patterns revealed by the mRNA study (sets 1 and 2). PAG1 was selected as the archetype of PAGs primarily expressed by the cotyledon (set 1), while PAG11 was considered to be typical of PAGs predominantly expressed in the intercotyledonary chorion of the placenta. Finally, we investigated the PAG2 protein that emerged as an atypical PAG representative of the ancient group.

\section{Characterization of antibodies}

Antibodies were purified as IgG using affinity chromatography with the natural protein PAG1 or peptides as ligands. The antibodies were characterized using protein

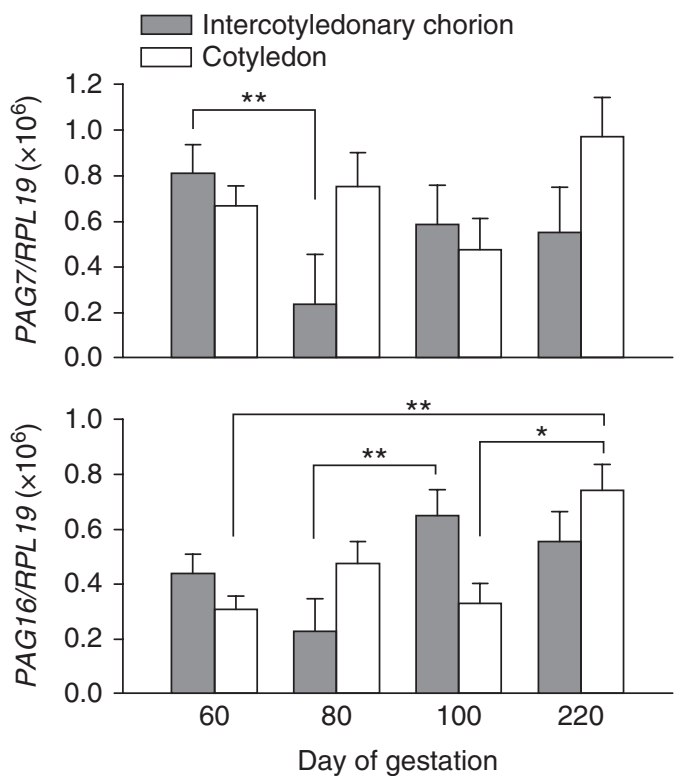

Figure 3 Expression of modern PAG7 and PAG16 in the placental chorion from 60 to $220 \mathrm{dpi}$. This group represents PAGs that are expressed at equivalent levels in the cotyledonary and intercotyledonary chorion ( $P>0.05$ for $P A G 7$ and PAG16). Intercotyledonary and cotyledonary chorion specimens were collected from pregnant cows at $60,80,100$ and 220 dpi (cows $=6-8$ per stage). PAG mRNAs were quantified by RT-qPCR and the results were normalized to RPL 19. Data are presented as mean \pm S.E.M. Pairwise tests of mean differences were performed after significant one-way ANOVA: ${ }^{*} P<0.05 ;{ }^{* *} P<0.01$. 

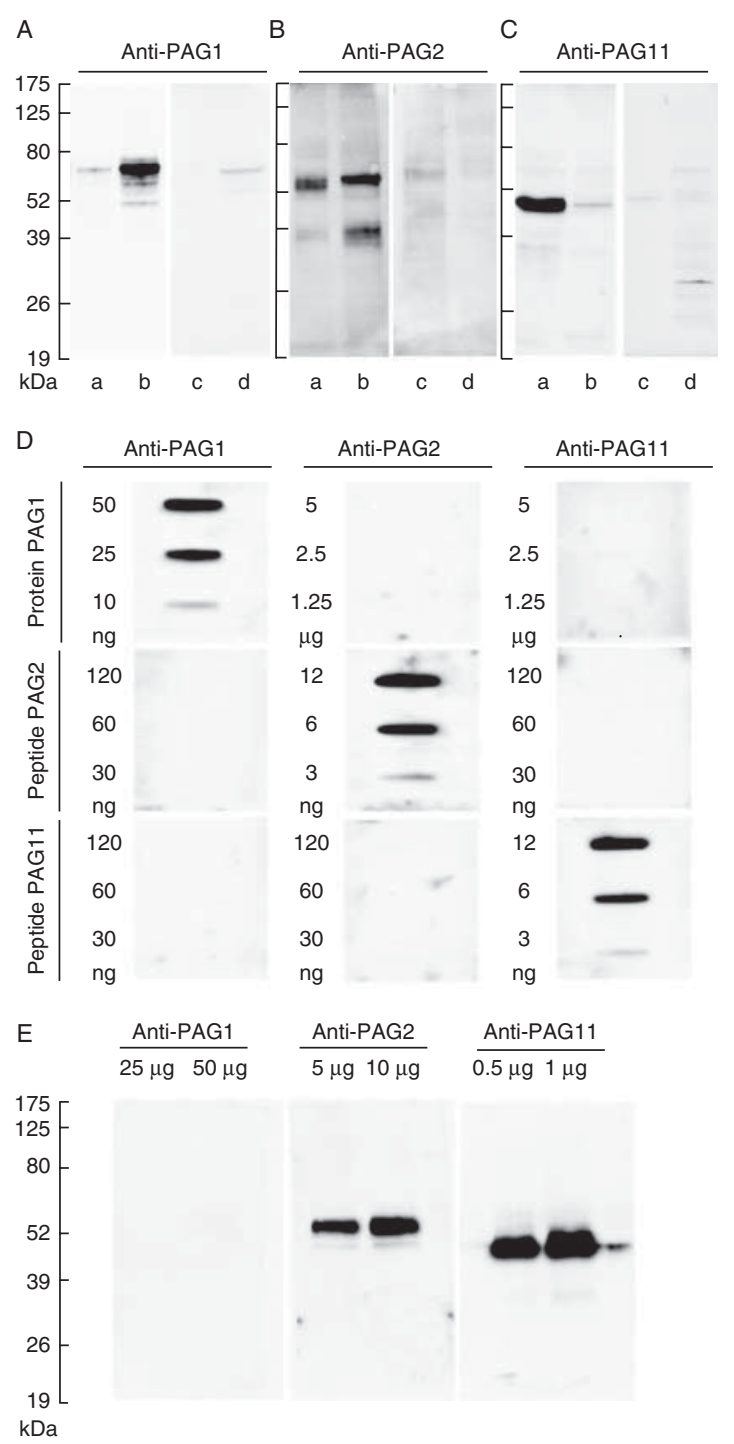

Figure 4 Validation of antibodies. (A, B and C) Western blot of PAG1, PAG2 and PAG11 in the bovine intercotyledonary and cotyledonary chorion at 220 days of gestation. Membranes were incubated in the presence of anti-PAG1 (L520) (A), anti-PAG2 (L390) (B) and anti-PAG11 (L349) (C) immunoglobulins in the intercotyledonary (a and c) and cotyledonary (b and d) chorion. Immunoneutralization was performed and involved the pre-incubation of antibodies in the presence of antigens (c and d). The antibodies revealed major bands at 67, 53 and $44 \mathrm{kDa}$ for PAG1, PAG2 and PAG11 respectively. (D) Slot blot of anti-PAG1, anti-PAG2 and anti-PAG11 against the purified PAG1 protein and PAG2 and PAG11 synthetic peptides. To evaluate crossreactivities, the protein and peptides were fixed in increasing quantities on membranes and incubated in the presence of anti-PAG1 (L520), anti-PAG2 (L390) or anti-PAG11 (L349). The anti-PAG1 revealed an immunoreactive signal only against the PAG1 protein, the anti-PAG2 only against the PAG2 peptide and the anti-PAG11 only against the PAG11 peptide. (E) Western blot of PAG1, PAG2 and PAG11 in day 16 bovine conceptuses. Increasing quantities of protein extracts were transferred onto membranes and incubated in the presence of antiPAG1 (L520), anti-PAG2 (L390) and anti-PAG11 (L349) immunoglobulins. The anti-PAG1 did not reveal any signal in the day 16 conceptuses, and the anti-PAG2 and anti-PAG11 revealed dose-related immunoreactive signals at 53 and $44 \mathrm{kDa}$ respectively. extracts from the cotyledon and intercotyledonary chorion at days 100 and 220. Only, data from day 220 were shown. Figure $4 \mathrm{~A}, \mathrm{~B}$ and $\mathrm{C}$ shows the western blot results for PAG1, PAG2 and PAG11 respectively. The anti-PAG1 antibody (L520) revealed a major band at $67 \mathrm{kDa}$ (Fig. 4A lanes a and b) that was suppressed when the purified native protein was used to immunoneutralize the antibody (Fig. 4A lanes $\mathrm{C}$ and d). The antiPAG2 antibody (L390) displayed a main band at $53 \mathrm{kDa}$ and a minor immunoreactive protein at $33 \mathrm{kDa}$ (Fig. 4B, lanes $a$ and $b$ ). These two signals were suppressed when the PAG2 antigenic peptide was used to immunoneutralize the immunoglobulin (Fig. 4B, lanes $\mathrm{C}$ and d). The PAG2 signal at $53 \mathrm{kDa}$ was eight times stronger than the $33 \mathrm{kDa}$ immunoreactive signal. PAG11 was evidenced as a unique protein band at $44 \mathrm{kDa}$ (Fig. 4C lanes a and b) with the anti-PAG11 (L349). Immunoneutralization of the antibody with the peptide resulted in disappearance of the protein signal (Fig. 4C lanes $c$ and d). The antibodies were examined for their cross-reactions in slot blot assays (Fig. 4D). The anti-PAG2 and anti-PAG11 antibodies did not recognize the purified PAG1 protein whereas they produced intensive signals against their respective antigenic peptide. The anti-PAG2 antibody did not display cross-reactivity with the PAG11 peptide even in the presence of significant amounts of the peptide. Similarly, the anti-PAG11 antibody did not cross-react with the PAG2 peptide. The anti-PAG1 antibody failed to recognize both the PAG2 peptide and the PAG11 peptide. An additional validation of the specificity of antibodies was performed using western blot of protein extracts from day 16 bovine conceptuses (Fig. 4E). Until day 25 of gestation, bovine conceptuses were known to not express PAG1 whereas they expressed PAG2 and PAG11 (Green et al. 2000). The fact that the anti-PAG1 antibody did not reveal any protein in the conceptus extract while anti-PAG2 and anti-PAG11 showed strong signal indicates that the antiPAG1 did not cross-react with PAG2 and PAG11 proteins. In the same protein extract, the anti-PAG2 and anti-PAG11 antibodies revealed proteins at different molecular masses, corresponding to the molecular masses recorded in Fig. 4B and C. Taken together, these different lines of evidence, in addition to results from deglycosylation experiments (see below), validate the specificity of the three antibodies used and the lack of cross-reactivity.

\section{Enzymatic N-deglycosylation of PAG1, PAG2 and PAG11 using PNGase-F}

Previous results obtained using SDS-PAGE had indicated apparent molecular masses of 67, 53 and $44 \mathrm{kDa}$ for PAG1, PAG2 and PAG11 respectively. The expected molecular mass of PAG polypeptides was around $37 \mathrm{kDa}$. PAGs are glycoproteins that are predicted to have up to six putative $\mathrm{N}$-glycosylation sites (Xie et al. 
A

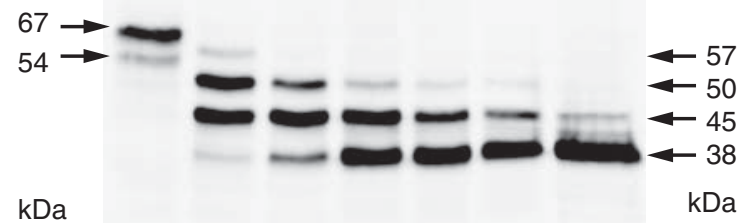

B

B

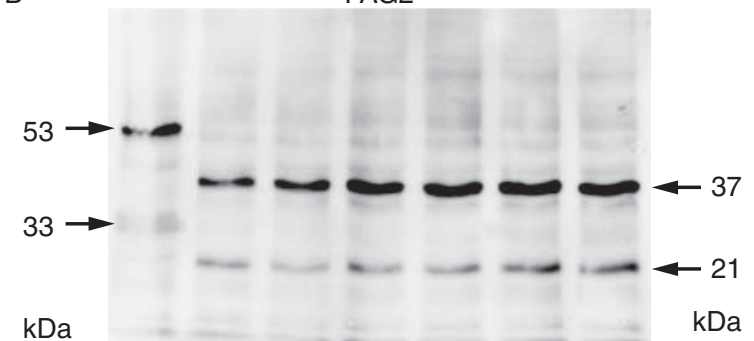

C

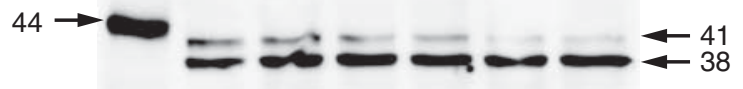

$\mathrm{kDa}$

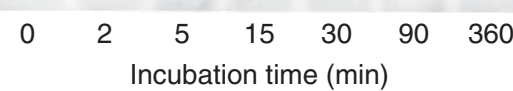

Figure 5 Enzymatic $\mathrm{N}$-deglycosylation using PNGase-F. Western blot revealed the enzymatic $N$-deglycosylation of PAG1 (A), PAG2 (B) and PAG11 (C). Proteins were extracted from the cotyledonary (A and B) and intercotyledonary (C) chorion at $220 \mathrm{dpi}$. Enzymatic N-deglycosylation was performed using PNGase-F for 0, 2, 5, 15, 30, 90 and $360 \mathrm{~min}$. During incubation, successive deglycosylation steps yielded $57,50,45$ and $38 \mathrm{kDa}$ bands from the native $67 \mathrm{kDa}$ PAG1. Fully glycosylated PAG2 at $53 \mathrm{kDa}$ shifted to $37 \mathrm{kDa}$ after deglycosylation. A minor anti-PAG2 immunoreactive band at $33 \mathrm{kDa}$ shifted to $21 \mathrm{kDa}$ Native PAG11 at $44 \mathrm{kDa}$ produced two deglycosylated proteins at 41 and $38 \mathrm{kDa}$ after the PNGase-F treatment.

1991, 1995, 1997, Klisch et al. 2005). We decided to reinforce the capacity of the antibodies generated in order to identify the different PAGs by examining the protein during an enzymatic deglycosylation process. PNGase- $F$ was used to eliminate sugar residues at the $\mathrm{N}$-amino glycosylation sites of the amino acid structure. To determine the number of glycosylation sites, PNGase-F was incubated for between 2 min and $3 \mathrm{~h}$ (Fig. 5). As depicted on the western blot, enzymatic digestion indicated five protein bands for PAG1 (Fig. 5A). The protein with the highest molecular mass was the native protein. The band for the smallest molecular mass $(37 \mathrm{kDa})$ corresponded to the entirely deglycosylated PAG1. Three bands were interposed between the native protein and the deglycosylated polypeptide, indicating four $\mathrm{N}$-glycosylation sites for PAG1. Digestion of the immunoreactive PAG2 protein generated one band at $37 \mathrm{kDa}$ (Fig. 5B), indicating that PAG2 displayed only one $\mathrm{N}$-glycosylation site. A minor immunoreactive protein detected at $33 \mathrm{kDa}$ shifted to $21 \mathrm{kDa}$, indicating that this protein was also N-glycosylated. Both glycosylated and deglycosylated forms of this protein were smaller than the expected size of the PAG2 polypeptide. We suggest that this protein is a truncated PAG2 resulting from proteolytic processing that might occur in vivo. The progressive deglycosylation of PAG11 resolved only one band at the polypeptide size $(38 \mathrm{kDa})$, suggesting only two N-glycosylation sites (Fig. 5C). Based on the shifts observed in western blot, glycan residues differed in size for the three PAGs examined: 6, 17 and 3 kDa for PAG1, PAG2 and PAG11 respectively.

\section{PAG profiles during gestation}

The antibodies thus characterized were then used to examine the expression of PAGs in cotyledonary and intercotyledonary regions in 60- to 220-day-old bovine placentas. Figures 6, 7 and 8 show typical western blot profiles and protein quantifications for PAG1, PAG2 and PAG11 respectively. The experiments were conducted four times on four different cows. Quantitative analysis of signal indicated that PAG1 was four times more concentrated in the cotyledon than in the intercotyledonary chorion $(P<0.001)$ (Fig. 6). A significant interaction was detected between day of gestation and placental zones $(P<0.01)$. This reflected the concomitant trend towards an increase in the amount of PAG1 in the cotyledon and a decrease in the amount of PAG1 in the intercotyledonary chorion. In the cotyledon, PAG1 was at a low concentration at day 60 and reached a maximum as soon as day 80 (day 60 vs day 80: $P<0.01$; day 60 vs day 220: $P<0.001)$. In the intercotyledonary chorion, a progressive threefold decrease from days 60 to 220 was observed for PAG1 $(P<0.01)$. Similar to PAG1, PAG2 was mainly detected in the cotyledons (Fig. 7). The protein was four times more concentrated in the cotyledon than in the intercotyledonary chorion $(P<0.001)$. The quantities of PAG2 in the intercotyledonary chorion displayed a twofold decrease as gestation progressed, detectable as soon as day 80 (day 60 vs day 80: $P<0.001$ ). The concentration of protein remained unchanged in cotyledons $(P>0.05)$. Contrary to PAG1 and PAG2, PAG11 was mostly detected in the intercotyledonary chorion (Fig. 8). The protein was four times more concentrated in the intercotyledonary chorion than in the cotyledon $(P<0.001)$. In the intercotyledonary chorion, PAG11 was consistently expressed at day 60 of gestation and remained at similar levels at days 80 and 100 . The concentration of the protein increased to reach its maximum levels at day 220 of gestation (day 60 vs day 


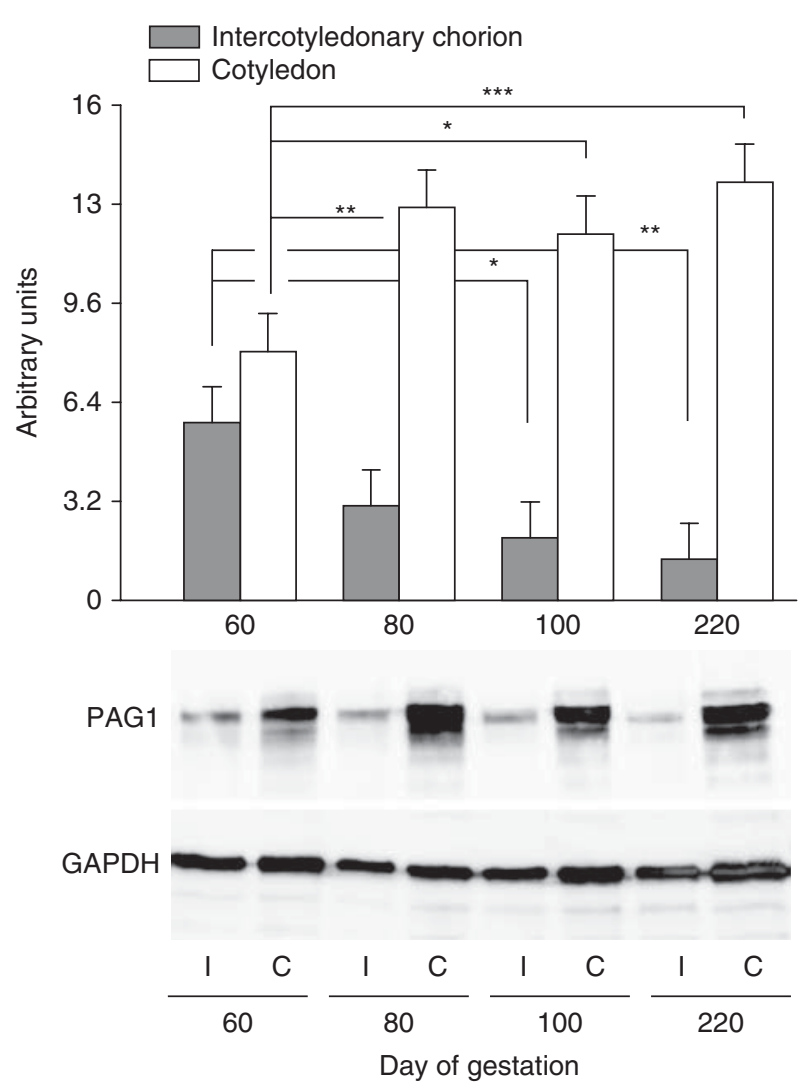

Figure 6 Western blot analyses of PAG1 protein in bovine intercotyledonary (I) and cotyledonary (C) chorion from 60 to 220 days of gestation. The histogram represents the quantification of $67 \mathrm{kDa}$ PAG1 in four independent blots representing four different cows. After PAG detection, the membranes were stripped and probed with antiGAPDH antibody to confirm the equal loading of samples onto the gel. Two-way ANOVA indicated that PAG1 was more concentrated in cotyledon than in intercotyledonary chorion $(P<0.001)$. Pairwise tests of mean differences were performed if one-way ANOVA showed significance: ${ }^{*} P<0.05 ;{ }^{* *} P<0.01 ;{ }^{* * *} P<0.001$.

220: $P<0.001)$. In the cotyledon, no changes in protein concentration were observed during the periods of gestation studied.

\section{Cellular localization of PAG1, PAG2 and PAG11}

In order to identify the cellular populations responsible for PAG synthesis, immunohistochemistry was performed on placentomes and intercotyledonary chorion sections at 60, 80, 100 and 220 days of gestation. Only the data relative to day 220 are shown. PAG1 was only detected in the cytoplasm of trophoblastic binucleate cells that were characterized by their round shape and large unstained circular nuclei (Fig. 9B, C and E). PAG1positive binucleate cells were numerous in placental villi of the whole placentome and in the interplacentomal trophoblastic cell layer (Fig. 9A and D). Mononucleate trophoblastic cells were not stained. Maternal tissues were unmarked.
PAG2 was mainly detected in trophoblastic placentomal cells (Fig. 10A). Rare cells were weakly labelled in the intercotyledonary regions (Fig. 10D and E). PAG2 staining was concentrated in the trophoblast cell layer surrounding binucleate cells that appeared to be unstained. The anti-PAG2 antibody labelled mononucleate trophoblastic cells that were cuboidal or columnar (Fig. 10C). PAG2-positive mononuclear cells were not equally distributed within the placentome. Mononucleate trophoblastic cells from secondary and tertiary villi were stained (Fig. 10C) whereas no signal was detected in the stem villi and chorionic plate (Fig. 10B).

The anti-PAG11 antibody labelled trophoblastic cells from both the placentome and the intercotyledonary chorion (Fig. 11A and D). In these two regions, PAG11 was only detected in trophoblastic binucleate cells. Mononucleate cells were unstained (Fig. 11B and E). In the placentome, only binucleate cells located at the chorionic plate were labelled (Fig. 11A and B) whereas binucleate cells in the secondary and tertiary villi were unstained (Fig. 11A and C). As for PAG1, numerous

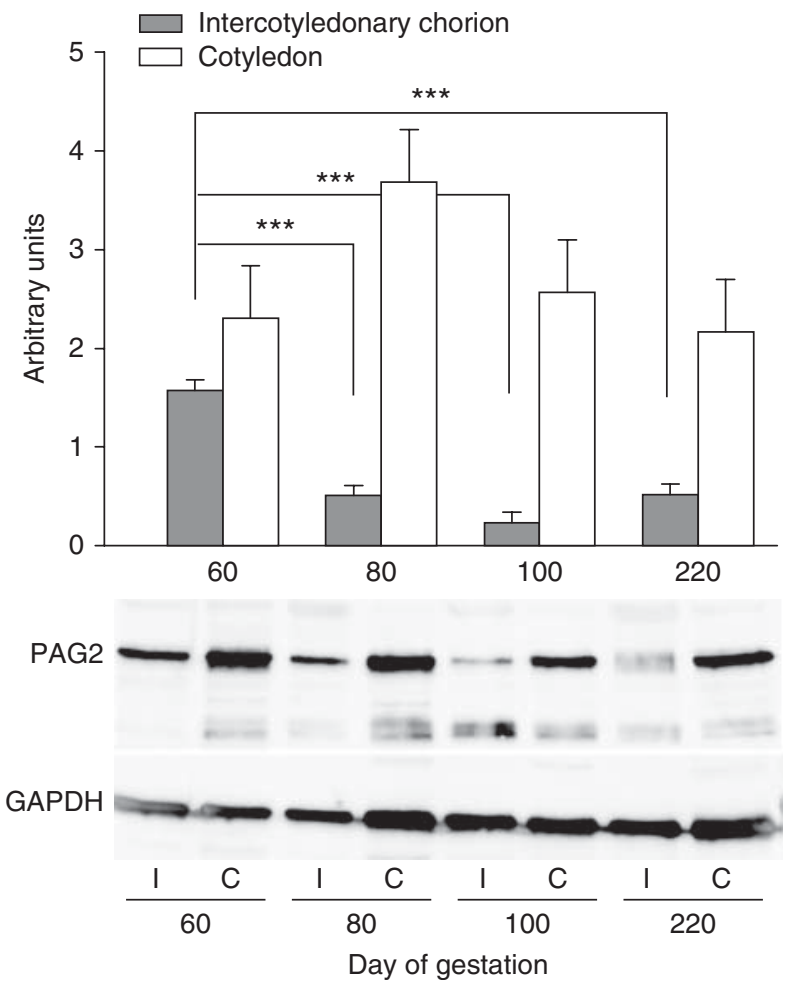

Figure 7 Western blot analyses of PAG2 protein in bovine intercotyledonary (I) and cotyledonary (C) chorion from 60 to 220 days of gestation. The histogram represents the quantification of $53 \mathrm{kDa}$ PAG2 in four independent blots representing four different cows. After PAG detection, the membranes were stripped and probed with anti-GAPDH antibody to confirm the equal loading of samples onto the gel. Two-way ANOVA indicated that PAG2 was more concentrated in cotyledon than in intercotyledonary chorion $(P<0.001)$. Pairwise tests of mean differences were performed if one-way ANOVA showed significance: $* * * P<0.001$. 

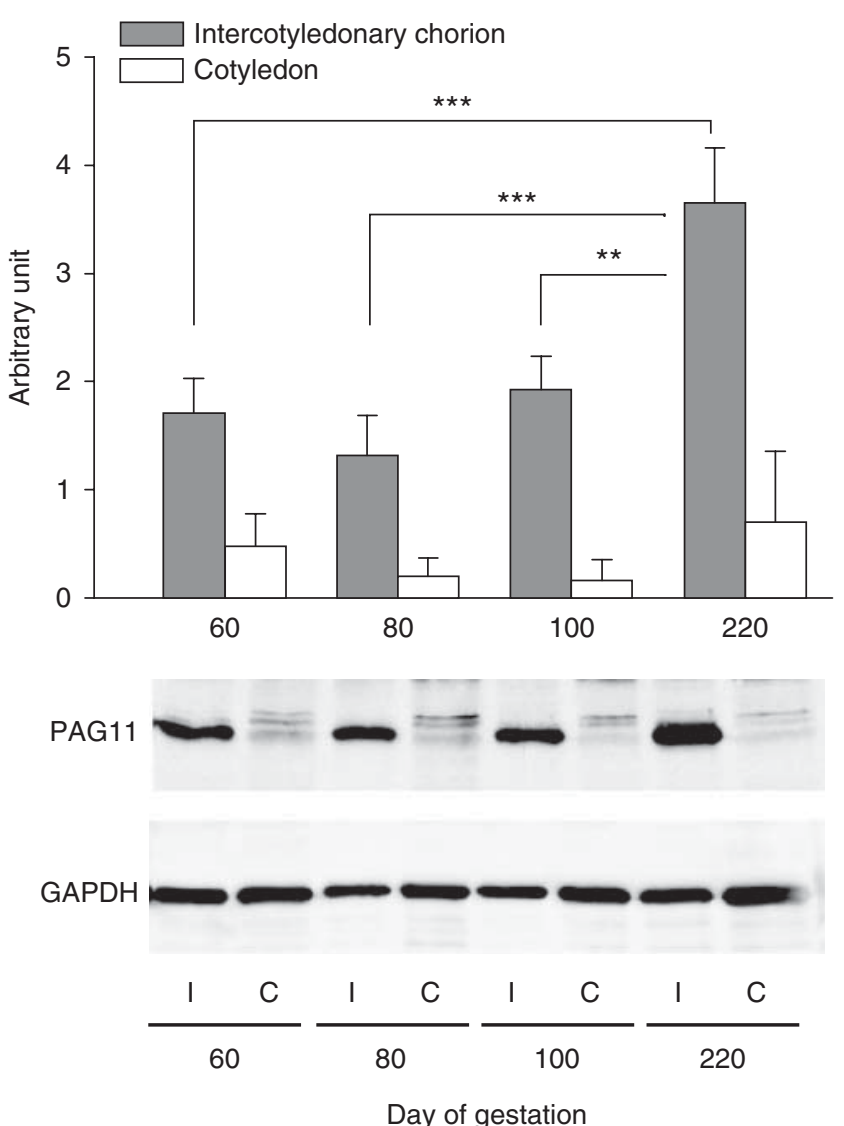

Figure 8 Western blot analyses of PAG11 protein in bovine intercotyledonary (I) and cotyledonary (C) chorion from 60 to 220 days of gestation. The histogram represents the quantification of $44 \mathrm{kDa}$ PAG11 in four independent blots representing four different cows. After PAG detection, the membranes were stripped and probed with anti-GAPDH antibody to confirm the equal loading of samples onto the gel. Two-way ANOVA indicated that PAG11 was more concentrated in intercotyledonary chorion than in cotyledon $(P<0.001)$. Pairwise tests of mean differences were performed after significant one-way ANOVA: ${ }^{* *} P<0.01 ;{ }^{* * *} P<0.001$.

binucleate cells in the intercotyledonary chorion were PAG11 positive (Fig. 11D and E). PAG11 was also characterized by homogenous cytoplasmic staining and was not detected in mononucleate cells. PAG1, PAG2 and PAG11 staining disappeared after immunoneutralization of the antibody with purified PAG1 protein or the corresponding peptides specific to PAG2 and PAG11 respectively (Figs 9F, 10F and 11F).

In the chorionic plate of the placentome and in the intercotyledonary chorion, both PAG1 and PAG11 were detected in binucleate trophoblastic cells. We tried to determine whether the antibodies targeted the same binucleate cells or whether PAG1 and PAG11 were synthesized by two distinct subpopulations of binucleate cells. Figure 12 shows the localization of PAG11 and PAG1 in the intercotyledonary chorion. PAG11 was revealed by anti-rabbit IgG-peroxidase antibody using NovaRed as the substrate and appears in red. PAG1 was revealed by anti-PAG IgG conjugated to alkaline phosphatase using VectorBlue as the chromogen substrate and appears in blue. PAG1-positive cells were mainly distributed in clusters and exceptionally as single positive cells throughout the trophoblastic layer of the chorion (Fig. 12A). No binucleate trophoblastic cells were recorded as being simultaneously stained with both PAG1 and PAG11 (Fig. 12B). Double-staining procedures using anti-PAG1 and anti-PAG2 antibodies are shown in Fig. 13. PAG1 was revealed in binucleate cells of the trophoblastic villi (Fig. 13A, B and C). Positive staining for PAG2 was clearly confined to mononucleate trophoblastic cells. No PAG2 staining was observed in binucleate cells expressing PAG1 (Fig. 13B and C).

\section{Discussion}

As far as we know, this is the first comparative study to have focused on the expression of ancient and modern PAGs in both the cotyledon and the intercotyledonary chorion of the bovine placenta. The innovative nature and relevance of our investigation were based on the use of advanced analytical tools for both transcript and

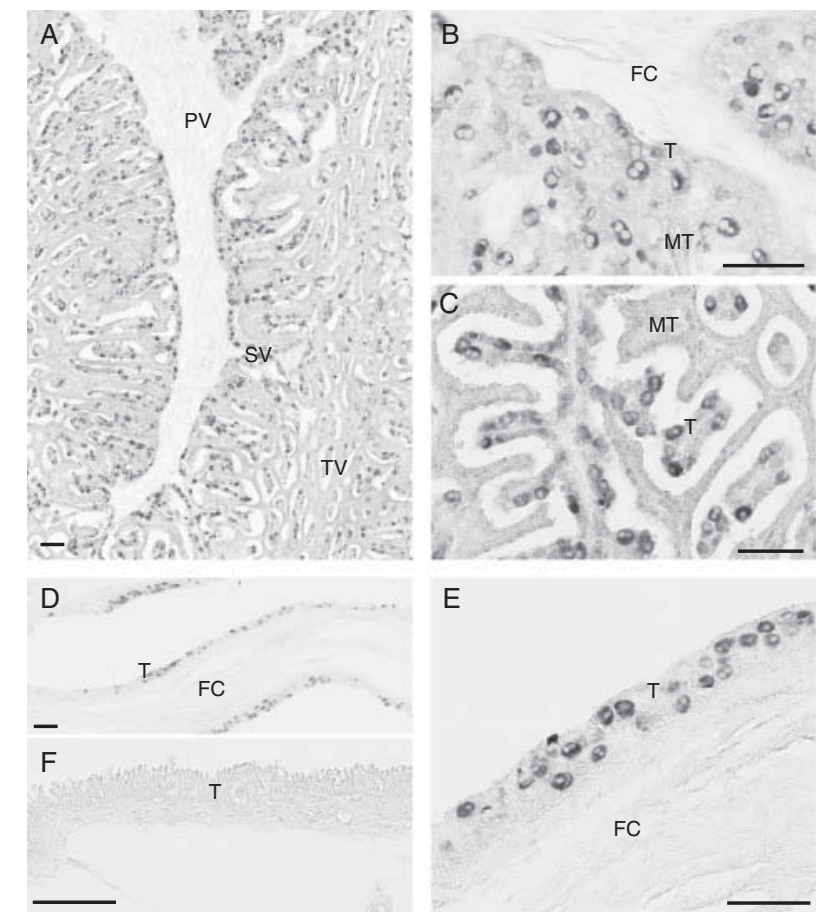

Figure 9 Immunohistochemistry of PAG1 protein in bovine placentomal (A, B and C) and interplacentomal (D, E and F) tissue sections at 220 days of gestation using the anti-PAG1 (L520) antibody. Panel A illustrates a global section of the placentome. Panel B illustrates the chorionic plate of the placentome. Panel C illustrates the internal secondary and tertiary villi. Panel F shows immunoneutralization of the anti-PAG1 antibody with the PAG1 protein. The anti-PAG1 antibody labelled only binucleate cells. PV, primary villi; SV, secondary villi; TV, tertiary villi; FC, foetal connective tissue; MT, maternal tissue; $\mathrm{T}$, trophoblast. Scale bar $=100 \mu \mathrm{m}$. 


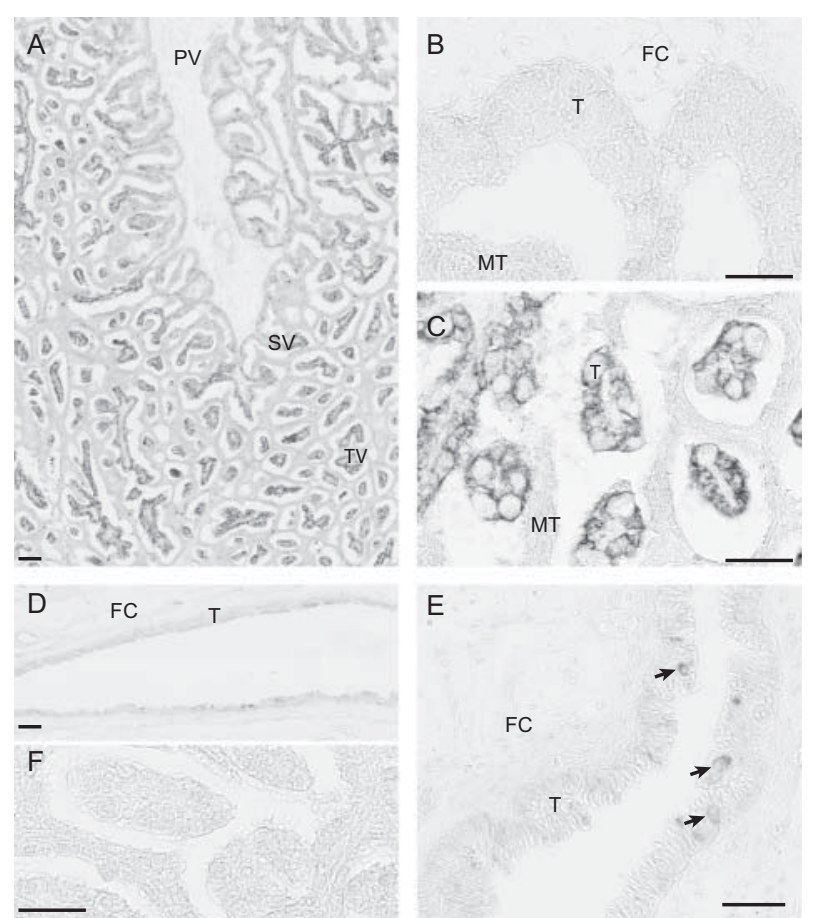

Figure 10 Immunohistochemistry of PAG2 protein in bovine placentomal (A, B, C and F) and interplacentomal (D and E) tissue sections at 220 days of gestation with the anti-PAG2 (L390) antibody. Panel A illustrates a global section of the placentome. Panel B illustrates the chorionic plate of the placentome. Panel C illustrates the internal secondary and tertiary villi. Panel $F$ shows immunoneutralization of the anti-PAG2 antibody with the antigenic peptide. The anti-PAG2 antibody-labelled mononucleate cells of the placentomal villi and faintly labelled them in the intercotyledonary chorion. PV, primary villi; SV, secondary villi; TV, tertiary villi; FC, foetal connective tissue; MT, maternal tissue; $\mathrm{T}$, trophoblast. (Arrows highlight mononucleate positive cells.) Scale bar $=100 \mu \mathrm{m}$.

protein analyses. Highly specific PCR primers were designed and stringently selected so as to ensure that only the correct PAG transcript was amplified. Consequently, we deliberately chose not to report data concerning PAG9, PAG13, PAG14, PAG18 and PAG20 as there remained some doubt about their specific amplification. Another important objective of this work was to precisely determine the expression and localization of PAG during gestation at the protein level. Rabbit polyclonal antibodies were raised against synthetic peptides conjugated to $\mathrm{KLH}$. During this study, antibody specificity was evaluated in various ways. The addition of an excess of blocking peptides or protein resulted in a loss of signal in both western blot and immunohistochemistry. No cross-reactivity between antibodies was reported. The fact that PAG are glycosylated proteins that could result in a multiple band pattern when running SDS-PAGE rendered validation of the antibodies more complex. Deglycosylation experiments demonstrated that antibodies recognized single bands of the expected molecular mass corresponding to the polypeptide chains. A key element demonstrating antibody specificity was provided by the correlation between the levels of protein and mRNA expression. A lack of signal in negative control tissues known not to express the PAGs (such as the endometrium) provided an additional line of evidence for validation of the antibodies.

To our knowledge, no other study has specifically addressed the expression of numerous PAGs in both the intercotyledonary areas and cotyledon of the bovine placenta. Using RNAse protection assays, one study (Green et al. 2000) reported that different PAG genes displayed different temporal patterns of expression during gestation, but it did not provide any information on the quantitative expression of transcripts and no data were collected with respect to the intercotyledonary chorion. Only two previous studies attempted to characterize and quantify the relative expression of PAG in the bovine placenta throughout gestation (Patel et al. 2004b, Telugu et al. 2009). Green's group (Telugu et al. 2009) established the differential expression profiles of PAG transcripts during gestation but solely
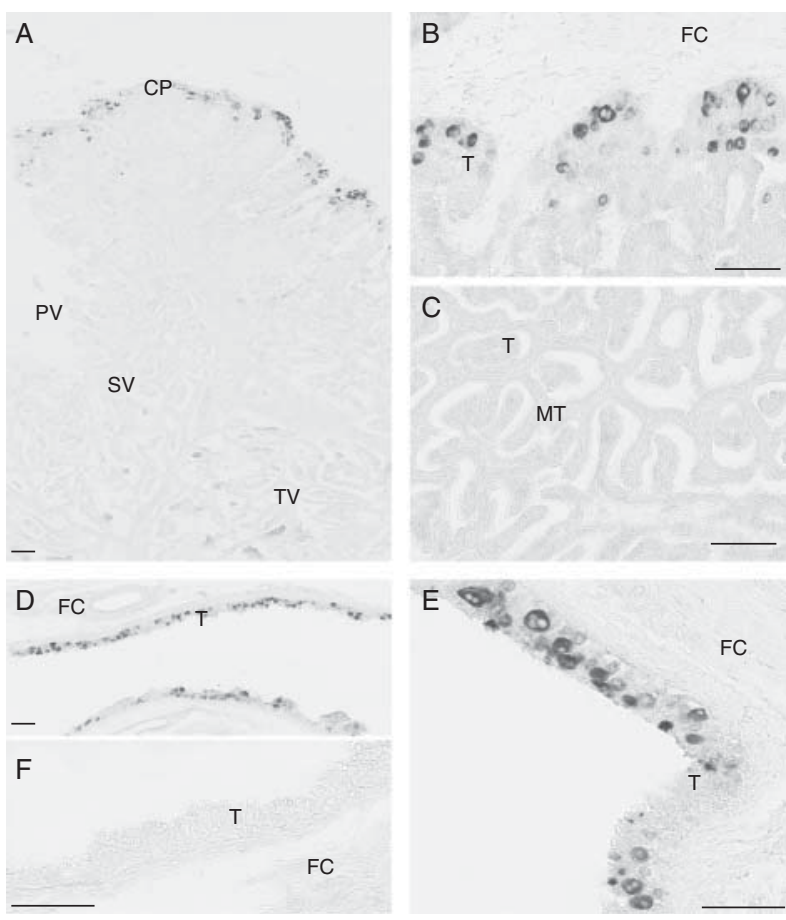

MT
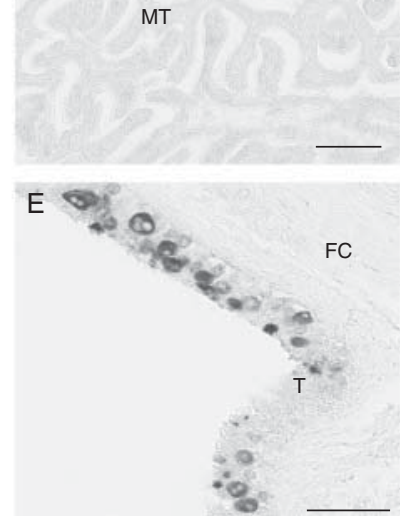

Figure $11 \mathrm{Imm}$ unohistochemistry of PAG11 protein in bovine placentomal (A, B and C) and interplacentomal (D, E and F) tissue sections at 220 days of gestation with the anti-PAG11 (L349) antibody. Panel A illustrates a global section of the placentome. Panel B illustrates the chorionic plate of the placentome. Panel C illustrates the internal secondary and tertiary villi. Panel F shows immunoneutralization of the anti-PAG11 antibody with the antigenic peptide. The anti-PAG11 labelled binucleate cells of the intercotyledonary chorion and chorionic plate of the placentome. PV, primary villi; SV, secondary villi; TV, tertiary villi; CP, chorionic plate; FC, foetal connective tissue; MT, maternal tissue; T, trophoblast. Scale bar $=100 \mu \mathrm{m}$. 


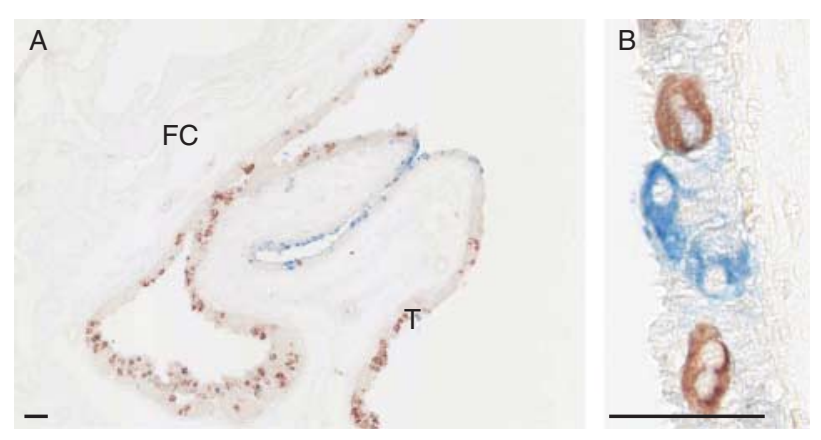

Figure 12 Localization of PAG1 and PAG11 proteins in bovine interplacentomal tissue sections at 220 days of gestation. Panel B is a higher magnification of the global view shown in panel A. Anti-PAG1 immunoglobulin was conjugated to alkaline phosphatase and visualized using Vector Blue alkaline phosphatase substrate and appeared in blue. Anti-PAG11 immunoglobulin was detected using a secondary biotinylated donkey anti-rabbit antibody revealed with an anti-biotin antibody conjugated to peroxidase. The immune complex was visualized using ImmPACt Novared peroxidase substrate and appeared in red. The anti-PAG1 and anti-PAG11 immunoglobulins identified distinct clusters of contiguous binucleate cells in the intercotyledonary chorion. FC, foetal connective tissue; T, trophoblast. Scale bar $=50 \mu \mathrm{m}$.

in the placental cotyledons, and only the ancient group of PAGs was examined. In our work, we were able to report that the expression of all PAGs increased as gestation progressed. PAG transcripts from the ancient group were more strongly expressed than those from the modern group. In addition, the most notable contribution of our work was to show that ancient PAGs were mainly expressed in the chorion of the intercotyledonary areas and to a lesser extent in the cotyledons. Despite the fact that the intercotyledonary chorion is considered not to play an essential role in placental function when compared with the cotyledon, the fact that ancient PAGs are expressed increasingly as gestation advances calls this into question. In the intercotyledonary chorion, the two most strongly expressed PAG transcripts were PAG8 and PAG10, levels of which increased 30-fold between days 60 and 220 of gestation. One exception in the ancient group was PAG2, which was expressed predominantly in the cotyledon. Regarding PAG2, our findings were consistent with those of Telugu et al. (2009). However, because their study was restricted to the cotyledon, a strict comparison of PAG expression profiles throughout the gestation between our results and those from Green's group (Telugu et al. 2009) would have been meaningless. With respect to PAG1, our results were in line with those of a previous report (Patel et al. 2004b), which showed a regular increase in PAG1 with advancing gestation and a stronger expression in cotyledonary than in intercotyledonary regions. However, contrary to our investigation, which examined more PAGs belonging to both the phylogenetic groups, the study by Patel et al. (2004b) was restricted to analysing the expression of two modern PAGs in the intercotyledonary region.
In order to present our results, we classified PAGs into three groups as a function of the area where they were mainly expressed, rather than dividing them according to phylogenetic affiliation. Among the five ancient PAGs investigated, four were principally expressed in the intercotyledonary chorion and three of these (PAG8, PAG10 and PAG11) exhibited increased levels of expression in line with gestation. As these PAGs were expressed at low and decreasing levels in the developing cotyledon, it could be suggested that their potential role is confined to the nonvillous chorion. The allocation of modern PAGs was less obvious. Among the modern PAGs supported by a substantial number of transcripts, three of them (PAG1, PAG3 and PAG15) were mainly expressed in the cotyledon. However, it was only at later stages of gestation that their transcript levels increased dramatically. The other half of the modern PAGs were spread equally between the intercotyledonary chorion and the cotyledon.

In line with previous studies (Xie et al. 1991, 1994, Zoli et al. 1991, Patel et al. 2004a, Klisch et al. 2006), anti-PAG1 antibodies showed that the main PAG1 protein has an approximate molecular mass of $67 \mathrm{kDa}$ and PAG1 has four potential sites for N-linked glycosylation (Xie et al. 1991, 1995). We demonstrated that the progressive deglycosylation of native PAG1 resulted in two deglycosylated intermediates and the fully deglycosylated protein at the molecular size expected for the polypeptide. Our findings indicated that PAG1 from placental tissue actually has four $\mathrm{N}$-glysosylated sites. This was consistent with a previous report (Patel et al. 2004a) on bovine PAG from an explant cultureconditioned medium. As for PAG11, we demonstrated experimentally that the two $\mathrm{N}$-glycosylation sites predicted by the amino acid analysis were actually glycosylated. The anti-PAG2 antibody revealed only one

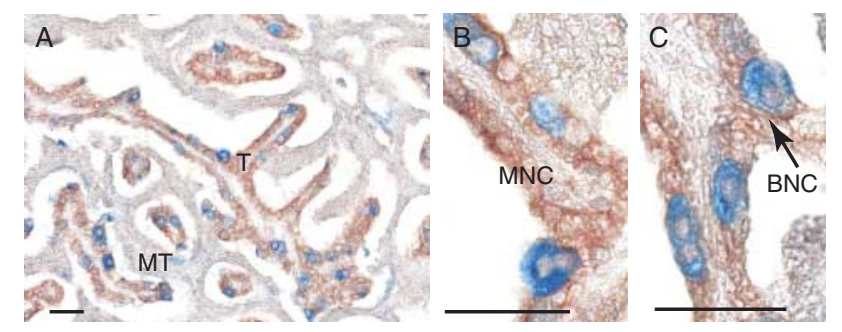

Figure 13 Localization of PAG1 and PAG2 proteins in bovine placentomal tissue sections at 220 days of gestation. Panels B and C are higher magnifications of the global view shown in panel A. Anti-PAG1 immunoglobulin was conjugated to alkaline phosphatase and visualized using Vector Blue alkaline phosphatase substrate and appeared in blue. Anti-PAG2 immunoglobulin was detected using a secondary biotinylated donkey anti-rabbit antibody revealed with an anti-biotin antibody conjugated to peroxidase. The immune complex was visualized using ImmPACt Novared peroxidase substrate and appeared in red. The double labelling identified PAG1 in binucleate cells and PAG2 in mononucleate cells of the placentome. MT, maternal tissue; $\mathrm{T}$, trophoblast; $\mathrm{MNC}$, mononucleate cell; BNC, binucleate cell. Scale bar $=50 \mu \mathrm{m}$. The arrow indicates a PAG1-positive binucleate cell. 
unambiguous $\mathrm{N}$-glysosylated site. The fact that PAG2 displayed a single $\mathrm{N}$-glycosylated site, although six potential positions were predicted, could have been related to folding of the protein (Apweiler et al. 1999). Moreover, we suggest that PAG2 is weakly glycosylated because the protein is synthesized by mononucleate cells (see below) that might lack the specific glycosylation machinery evidenced in binucleate cells (Klisch \& Leiser 2003). Global changes to PAG glycosylation have been reported during gestation (Klisch et al. 2006, 2008) but the precise protein involved has not yet been identified. As PAGs display different patterns of expression during gestation, and because we showed that their glycan residues differ in size, it could be suggested that PAG might to some extent be involved in global changes to glycosylation.

It is generally accepted that modern PAGs are only expressed in binucleate cells of the cotyledonary trophoblast, whereas the ancient group (exemplified by PAG2) is expressed in both mononucleate and binucleate trophoblastic cells of the cotyledons. Our results did not exactly fit this model. We showed that the ancient PAG2 was exclusively localized in mononucleate trophoblastic cells whereas PAG11, another ancient PAG, was exclusively localized in binucleate cells. Using in situ hybridization, Roberts' group was the first to suggest that PAGs from the ancient group are expressed in both mono- and binucleate cells, while modern PAG expression is limited to binucleate cells (Xie et al. 1994). However, when their experiments were performed, the diversity of the PAG family was unknown and, as pointed out later (Green et al. 2000), it is likely that the long probes commonly used for in situ hybridization lacked specificity and should have crossreacted with both modern and ancient PAGs (Xie et al. 1994). Using immunohistochemistry, a more recent study supported the localization of ancient PAGs in both mononucleate and binucleate trophoblastic cells (Wooding et al. 2005). However, as suggested by the authors themselves, the precise specificity of the antibodies they used was not rigorously defined (Wooding et al. 2005). Their antibodies were raised using a protein fraction from affinity chromatography eluting at a neutral $\mathrm{pH}$, which supposedly generated ancient PAGs (Green et al. 2005). However, to our knowledge, this has never been clearly demonstrated. Indeed, using mass spectrometry, it had been demonstrated (Green et al. 2005) that the antibodies raised against proteins eluting at a neutral $\mathrm{pH}$ only recognized PAGs from the modern group. We claim that the data inferred from our immunohistochemistry study were reliable because our antibodies were raised against specific peptides designed to differentiate PAGs. Both the two ancient PAGs we examined - PAG11 and PAG2 were exclusively expressed in a single cell type. Our results therefore suggest that each PAG displays a unique cellular localization in either mononucleate or binucleate cells. The question remains as to whether this pattern applies to all PAGs. Further studies are needed to examine this issue by including more PAGs from each phylogenetic group.

PAG1 was localized in binucleate cells of both the intercotyledonary and the cotyledonary chorion. Mononucleate cells expressing PAG2 were mainly detected in the cotyledon and only faintly in the intercotyledonary chorion. PAG11 was detected in binucleate cells of both the intercotyledonary and the cotyledonary chorion. However, unlike PAG1, which was detected in binucleate cells of the whole cotyledon, PAG11 was restricted to binucleate cells situated in the chorionic plate of the cotyledon. No binucleate cells expressing PAG11 were detected in the primary and secondary villi of the cotyledon. These results argue in favour of two populations of binucleate cells. Previous studies reported that the anatomical localization of binucleate cells in the ruminant placenta was associated with substantial differences in glycoprotein content (Lee et al. 1986, Wooding et al. 1996), but no evidence was provided regarding PAG synthesis. We addressed this issue by studying PAG1 and PAG11 co-localization. Our results demonstrated that two distinct cell populations synthesize PAG1 and PAG11, whereas no binucleate cells co-expressing the two proteins were detected. Moreover, in the intercotyledonary chorion, binucleate cells were observed as clusters of contiguous positive cells. Clumps of PAG1-positive binucleate cells were interspersed with those of PAG11-positive cells. These observations call into question the propagation of similar phenotypes in adjacent binucleate cells. Local factors might be suggested to explain differences in the gene expression pattern. Similar gene expression patterns would be observed for binucleate cells in the immediate vicinity while cells at a distant location would display another expression pattern. The way binucleate cells are generated should also be considered. It is generally accepted that binucleate cells originate from mononucleate cells by means of single acytokinetic mitosis (Wimsatt 1951, Wooding 1992, Wooding et al. 1994). Our results showing alternating aggregates of cells with similar phenotypes suggest that all the cells sharing a similar pattern of expression originated from a single cell. This is consistent with a previous suggestion (Wooding \& Flint 1994) that any mononucleate trophoblastic cell can produce two cells, one of them leading to a binucleate cell through acytokinetic mitosis while the other remains as a mononucleate cell. Successive cell divisions of the latter will result in the generation of numerous binucleate cells sharing the same phenotype, as observed in our study.

Our findings highlight the important production of ancient PAG in the intercotyledonary trophoblast. This raises questions as to the role of proteins produced in such large quantities. Moreover, the evidence of PAG11 localization in binucleate cells suggests that it is possible 
for an ancient PAG to reach the maternal blood circulation where none was previously evidenced. This suggestion is coherent in view of the ability of intercotyledonary binucleate cells to fuse with maternal cells as has been described in mouse deer presenting diffuse placentation (Wooding et al. 2007). This possibility implies putative functions for ancient PAGs, either within binucleate cells, during migration of the cells or in intercotyledonary areas of maternal tissues.

In summary, we have demonstrated that the levels of most of PAGs rise during gestation. Their expression patterns segregated into three distinct sets. PAGs from the ancient phylogenetic group were mainly expressed in the intercotyledonary chorion whereas modern PAGs were principally expressed in the cotyledon. One exception was PAG2, which is an ancient PAG, which was almost exclusively synthesized in the cotyledon. Moreover, we determined that PAGs were allocated to distinct trophoblastic cell populations. PAG2 was localized in mononucleate cells of the cotyledonary villi, PAG11 in binucleate cells of both the intercotyledonary region and the chorionic plate of the cotyledon and PAG1 in binucleate cells of both the intercotyledonary and the cotyledonary chorion.

\section{Declaration of interest}

The authors declare that there is no conflict of interest that could be perceived as prejudicing the impartiality of the research reported.

\section{Funding}

E Touzard was supported by a CIFRE (Convention Industrielle de Formation par la Recherche) scholarship from MESR (Ministère de I'Enseignement Supérieur et de la Recherche) via the ANRT (Association Nationale de la Recherche et de la Technologie).

\section{Acknowledgements}

The authors would like to thank Cyril Gonzalez and Michel Baratte for their technical assistance with animal management. They are grateful to Sylvaine Camous for fruitful discussions and Olivier Sandra for his pertinent advice. They also would like to thank Vicky Hawken for English language editing.

\section{References}

Apweiler R, Hermjakob H \& Sharon N 1999 On the frequency of protein glycosylation, as deduced from analysis of the SWISS-PROT database. Biochimica et Biophysica Acta $\mathbf{1 4 7 3}$ 4-8. (doi:10.1016/S03044165(99)00165-8)

Bridges PJ, Weems YS, Kim LM, Sasser RG, LeaMaster BR, Vincent DL \& Weems CW 1999 Effect of PGF2 $\alpha$, indomethacin, tamoxifen, or estradiol-17 $\beta$ on incidence of abortion, progesterone, and pregnancy-specific protein B (PSPB) secretion in 88- to 90-day pregnant sheep. Prostaglandins \& Other Lipid Mediators 58 113-124. (doi:10.1016/S0090-6980(99)00045-3)

Butler JE, Hamilton WC, Sasser RG, Ruder CA, Hass GM \& Williams RJ 1982 Detection and partial characterization of two bovine pregnancyspecific proteins. Biology of Reproduction 26 925-933. (doi:10.1095/ biolreprod26.5.925)

Camous S, Charpigny G, Guillomot M \& Martal J 1988 Purification of one bovine pregnancy-specific protein by high-performance liquid chromatography (HPLC). Proceedings of the International Workshop on Maternal Recognition of Pregnancy and Maintenance of the Corpus Luteum, Jerusalem Israel, Kimron Veterinary Institute, Israel Abstr no. 59.

Chomczynski P \& Sacchi N 1987 Single-step method of RNA isolation by acid guanidinium thiocyanate-phenol-chloroform extraction. Analytical Biochemistry 162 156-159. (doi:10.1016/0003-2697(87)90021-2)

Constant F, Camous S, Chavatte-Palmer P, Heyman Y, de Sousa N, Richard C, Beckers JF \& Guillomot M 2011 Altered secretion of pregnancy-associated glycoproteins during gestation in bovine somatic clones. Theriogenology 76 1006-1021. (doi:10.1016/j.theriogenology. 2011.04.029)

Dosogne H, Burvenich C, Freeman AE, Kehrli ME Jr, Detilleux JC, Sulon J, Beckers JF \& Hoeben D 1999 Pregnancy-associated glycoprotein and decreased polymorphonuclear leukocyte function in early post-partum dairy cows. Veterinary Immunology and Immunopathology 67 47-54. (doi:10.1016/S0165-2427(98)00215-3)

Dosogne H, Massart-Leen AM \& Burvenich C 2000 Immunological aspects of pregnancy-associated glycoproteins. Advances in Experimental Medicine and Biology 480 295-305. (doi:10.1007/0-306-46832-8_34)

Green JA, Xie S \& Roberts RM 1998 Pepsin-related molecules secreted by trophoblast. Reviews of Reproduction 3 62-69. (doi:10.1530/ror.0. 0030062)

Green JA, Xie S, Quan X, Bao B, Gan X, Mathialagan N, Beckers JF \& Roberts RM 2000 Pregnancy-associated bovine and ovine glycoproteins exhibit spatially and temporally distinct expression patterns during pregnancy. Biology of Reproduction 62 1624-1631. (doi:10.1095/ biolreprod62.6.1624)

Green JA, Parks TE, Avalle MP, Telugu BP, McLain AL, Peterson AJ, McMillan W, Mathialagan N, Hook RR, Xie S et al. 2005 The establishment of an ELISA for the detection of pregnancy-associated glycoproteins (PAGs) in the serum of pregnant cows and heifers. Theriogenology 63 1481-1503. (doi:10.1016/j.theriogenology.2004.07.011)

Hughes AL, Green JA, Garbayo JM \& Roberts RM 2000 Adaptive diversification within a large family of recently duplicated, placentally expressed genes. PNAS 97 3319-3323. (doi:10.1073/pnas.97.7.3319)

Igwebuike UM 2006 Trophoblast cells of ruminant placentas - a minireview. Animal Reproduction Science 93 185-198. (doi:10.1016/j. anireprosci.2005.06.003)

Klisch K \& Leiser R 2003 In bovine binucleate trophoblast giant cells, pregnancy-associated glycoproteins and placental prolactin-related protein-I are conjugated to asparagine-linked $\mathrm{N}$-acetylgalactosaminyl glycans. Histochemistry and Cell Biology 119 211-217. (doi:10.1007/ s00418-003-0507-6)

Klisch K, De Sousa NM, Beckers JF, Leiser R \& Pich A 2005 Pregnancy associated glycoprotein-1, $-6,-7$, and -17 are major products of bovine binucleate trophoblast giant cells at midpregnancy. Molecular Reproduction and Development 71 453-460. (doi:10.1002/mrd.20296)

Klisch K, Boos A, Friedrich M, Herzog K, Feldmann M, Sousa N, Beckers J, Leiser R \& Schuler G 2006 The glycosylation of pregnancy-associated glycoproteins and prolactin-related protein-I in bovine binucleate trophoblast giant cells changes before parturition. Reproduction 132 791-798. (doi:10.1530/REP-06-0040)

Klisch K, Jeanrond E, Pang PC, Pich A, Schuler G, Dantzer V, Kowalewski MP \& Dell A 2008 A tetraantennary glycan with bisecting $\mathrm{N}$-acetylglucosamine and the $\mathrm{Sd}(\mathrm{a})$ antigen is the predominant $\mathrm{N}$-glycan on bovine pregnancy-associated glycoproteins. Glycobiology 18 42-52. (doi:10.1093/glycob/cwm113)

Kolaskar AS \& Tongaonkar PC 1990 A semi-empirical method for prediction of antigenic determinants on protein antigens. FEBS Letters 276 172-174. (doi:10.1016/0014-5793(90)80535-Q)

Lee CS, Gogolin-Ewens K \& Brandon MR 1986 Comparative studies on the distribution of binucleate cells in the placentae of the deer and cow using the monoclonal antibody, SBU-3. Journal of Anatomy 147 163-179. 
Mialon MM, Camous S, Renand G, Martal J \& Menissier F 1993 Peripheral concentrations of a $60-\mathrm{kDa}$ pregnancy serum protein during gestation and after calving and in relationship to embryonic mortality in cattle. Reproduction, Nutrition, Development 33 269-282. (doi:10.1051/ rnd:19930309)

Patel OV, Takahashi T, Imai K \& Hashizume K 2004a Characterization of native and recombinant bovine pregnancy-associated glycoproteins. Research in Veterinary Science 77 203-210. (doi:10.1016/j.rvsc.2004. 05.003)

Patel OV, Yamada O, Kizaki K, Takahashi T, Imai K \& Hashizume K 2004b Quantitative analysis throughout pregnancy of placentomal and interplacentomal expression of pregnancy-associated glycoproteins-1 and -9 in the cow. Molecular Reproduction and Development 67 257-263. (doi:10.1002/mrd.20017)

Rice P, Longden I \& Bleasby A 2000 EMBOSS: the European Molecular Biology Open Software Suite. Trends in Genetics 16 276-277. (doi:10.1016/S0168-9525(00)02024-2)

Sasser RG, Ruder CA, Ivani KA, Butler JE \& Hamilton WC 1986 Detection of pregnancy by radioimmunoassay of a novel pregnancy-specific protein in serum of cows and a profile of serum concentrations during gestation. Biology of Reproduction 35 936-942. (doi:10.1095/biolreprod35.4.936)

Szafranska B, Panasiewicz G \& Majewska M 2006 Biodiversity of multiple pregnancy-associated glycoprotein (PAG) family: gene cloning and chorionic protein purification in domestic and wild eutherians (Placentalia) - a review. Reproduction, Nutrition, Development 46 481-502. (doi:10.1051/rnd:2006034)

Telugu BP, Walker AM \& Green JA 2009 Characterization of the bovine pregnancy-associated glycoprotein gene family - analysis of gene sequences, regulatory regions within the promoter and expression of selected genes. BMC Genomics 10 185. (doi:10.1186/1471-2164-10185)

Thompson IM, Tao S, Branen J, Ealy AD \& Dahl GE 2012 Environmental regulation of pregnancy-specific protein $B$ concentrations during late pregnancy in dairy cattle. Journal of Animal Science 91 168-173. (doi:10.2527/jas.2012-5730)

Weems YS, Lammoglia MA, Vera-Avila HR, Randel RD, King C, Sasser RG \& Weems CW 1998 Effect of luteinizing hormone (LH), PGE2, 8-EPIPGE1, 8-EPI-PGE2, trichosanthin, and pregnancy specific protein B (PSPB) on secretion of progesterone in vitro by corpora lutea $(\mathrm{CL})$ from nonpregnant and pregnant cows. Prostaglandins \& Other Lipid Mediators 55 27-42. (doi:10.1016/S0090-6980(98)00003-3)

Weems YS, Lammoglia MA, Lewis AW, Randel RD, Sasser RG, Morita I \& Weems CW 1999 PGE2 induces its own secretion in vitro by bovine 270-day placenta but not by 200-day placenta. Prostaglandins \& Other Lipid Mediators 57 189-205. (doi:10.1016/S0090-6980(99)00003-9)

Weems YS, Bridges PJ, LeaMaster BR, Sasser RG, Ching L \& Weems CW 2001 Effect of the aromatase inhibitor CGS-16949A on pregnancy and secretion of progesterone, estradiol-17 $\beta$, prostaglandins E and F2 $\alpha$ (PGE; PGF2 $\alpha$ ) and pregnancy specific protein B (PSPB) in 90-day ovariectomized pregnant ewes. Prostaglandins \& Other Lipid Mediators 66 77-88. (doi:10.1016/S0090-6980(01)00144-7)

Wimsatt WA 1951 Observations on the morphogenesis, cytochemistry, and significance of the binocleate giant cells of the placenta of ruminants. American Journal of Anatomy 89 233-281. (doi:10.1002/aja.1000 890204)

Wooding FB 1983 Frequency and localization of binucleate cells in the placentomes of ruminants. Placenta 4 527-539.
Wooding FB 1992 Current topic: the synepitheliochorial placenta of ruminants: binucleate cell fusions and hormone production. Placenta 13 101-113. (doi:10.1016/0143-4004(92)90025-O)

Wooding FBP \& Flint APF 1994 Placentation. In Marshall's Physiology of Reproduction, 4th edn, pp 230-466. Ed GE Lamming. London: Chapman and Hall.

Wooding FB \& Wathes DC 1980 Binucleate cell migration in the bovine placentome. Journal of Reproduction and Fertility 59 425-430. (doi:10.1530/jrf.0.0590425)

Wooding FB, Morgan G, Brandon MR \& Camous S 1994 Membrane dynamics during migration of placental cells through trophectodermal tight junctions in sheep and goats. Cell and Tissue Research 276 387-397. (doi:10.1007/BF00306124)

Wooding FB, Morgan G, Jones GV \& Care AD 1996 Calcium transport and the localisation of calbindin-D9k in the ruminant placenta during the second half of pregnancy. Cell and Tissue Research 285 477-489. (doi:10.1007/s004410050664)

Wooding FB, Roberts RM \& Green JA 2005 Light and electron microscope immunocytochemical studies of the distribution of pregnancy associated glycoproteins (PAGs) throughout pregnancy in the cow: possible functional implications. Placenta 26 807-827. (doi:10.1016/j.placenta. 2004.10.014)

Wooding FB, Kimura J, Fukuta K \& Forhead AJ 2007 A light and electron microscopical study of the Tragulid (mouse deer) placenta. Placenta $\mathbf{2 8}$ 1039-1048. (doi:10.1016/j.placenta.2007.04.010)

Xie SC, Low BG, Nagel RJ, Kramer KK, Anthony RV, Zoli AP, Beckers JF \& Roberts RM 1991 Identification of the major pregnancy-specific antigens of cattle and sheep as inactive members of the aspartic proteinase family. PNAS 88 10247-10251. (doi:10.1073/pnas.88.22.10247)

Xie S, Low BG, Nagel RJ, Beckers JF \& Roberts RM 1994 A novel glycoprotein of the aspartic proteinase gene family expressed in bovine placental trophectoderm. Biology of Reproduction 51 1145-1153. (doi:10.1095/biolreprod51.6.1145)

Xie S, Green J, Beckers JF \& Roberts RM 1995 The gene encoding bovine pregnancy-associated glycoprotein-1, an inactive member of the aspartic proteinase family. Gene 159 193-197. (doi:10.1016/03781119(94)00928-L)

Xie S, Green J, Bixby JB, Szafranska B, DeMartini JC, Hecht S \& Roberts RM 1997 The diversity and evolutionary relationships of the pregnancyassociated glycoproteins, an aspartic proteinase subfamily consisting of many trophoblast-expressed genes. PNAS 94 12809-12816. (doi:10.1073/pnas.94.24.12809)

Zoli AP, Beckers JF, Wouters-Ballman P, Closset J, Falmagne P \& Ectors F 1991 Purification and characterization of a bovine pregnancy-associated glycoprotein. Biology of Reproduction 45 1-10. (doi:10.1095/biolreprod45.1.1)

Zoli AP, Demez P, Beckers JF, Reznik M \& Beckers A 1992 Light and electron microscopic immunolocalization of bovine pregnancyassociated glycoprotein in the bovine placentome. Biology of Reproduction 46 623-629. (doi:10.1095/biolreprod46.4.623)

Received 8 April 2013

First decision 2 May 2013

Revised manuscript received 3 May 2013

Accepted 15 July 2013 